\title{
geosciences
}

ISSN 2076-3263

www.mdpi.com/journal/geosciences

Article

\section{Cretaceous-Paleogene Dinoflagellate Biostratigraphy and the Age of the Clayton Formation, Southeastern Missouri, USA}

\author{
Natalie R. Dastas ${ }^{1, *}$, John A. Chamberlain, Jr. ${ }^{1,2,3}$ and Matthew P. Garb ${ }^{2}$
}

1 Earth and Environmental Sciences, City University of New York Graduate Center, New York, NY 10016, USA; E-Mail: johnc@brooklyn.cuny.edu

2 Department of Earth and Environmental Sciences, Brooklyn College, Brooklyn, NY 11210, USA;

E-Mail:mgarb@brooklyn.cuny.edu

3 Biology, City University of New York Graduate Center, New York, NY 10016, USA

* Author to whom correspondence should be addressed; E-Mail: ndastas@gc.cuny.edu; Tel.: +1-718-951-5416; Fax: +1-718-951-4753.

Received: 31 December 2013; in revised form: 17 February 2014 / Accepted: 19 February 2014 / Published: 7 March 2014

\begin{abstract}
Sedimentary deposits in Stoddard County, southeastern Missouri, reveal a K-Pg transition sequence represented by the uppermost Maastrichtian Owl Creek Formation and the Paleocene Clayton Formation. The Clayton Formation is characterized by a basal fossiliferous coquinite that contains reworked late Maastrichtian macrofossils. Dinoflagellate biostratigraphy is used to determine the age of the coquinite layer and specifically whether or not it is an end-K tsunamite deposit resulting from the Chicxulub impact event. Results indicate a mixed assemblage of late Maastrichtian and early Danian dinocysts within the basal coquinite of the Clayton Formation. Maastrichtian dinocyst taxa identified are Riculacysta amplexa, Pierceites pentagonus, Phelodinium tricuspe and Dinogymnium sp. and dinocysts utilized as global indicators of the basal Danian, also present in the coquinite, consist of Senoniasphaera inornata, Carpatella cornuta, Damassadinium californicum, and Lanternosphaeridium reinhardtii. A gray mud occurring above the coquinite in the middle of the Clayton Formation contains the mid-Danian dinoflagellate Senegalinium iterlaaense. Collectively, these data suggest that the coquinite was deposited well after the K-Pg event but before the middle Danian. The mixed assemblage of Late Cretaceous and Paleocene dinocysts preserved in the coquinite weakens the hypothesis that it is an end-K tsunamite deposit and suggests instead that it may result from a long-term transgressive lag. We also extend the stratigraphic range of the Paleocene Senegalinium simplex downward into the uppermost Maastrichtian.
\end{abstract}


Keywords: K-Pg; dinoflagellate; Mississippi embayment; stratigraphy; Clayton Formation

\section{Introduction}

The Mississippi embayment is a long, narrow basin located between the Appalachian Highlands and the Ozark Plateaus (Figure 1). Preserved in the Mississippi Embayment are sediments that were deposited within an early Late Cretaceous epeiric sea that invaded the continent as a result of regional subsidence [1]. Sedimentary deposits near the head of the embayment range from Cretaceous to Quaternary in age [2-4] and in some localities are known to contain the Cretaceous-Paleogene (K-Pg) boundary interval [5-7].

Figure 1. Late Cretaceous shoreline for eastern and central regions of the United States from [8]. ME: Mississippi Embayment. Inset: location of the study site (star) in Stoddard County, Missouri near the towns of Bloomfield and Bell City. Dashed line: Stoddard County boundary. Global coordinates of study site: $36^{\circ} 55^{\prime} 15^{\prime \prime} \mathrm{N} ; 89^{\circ} 52^{\prime 2} 2^{\prime \prime} \mathrm{W}$.

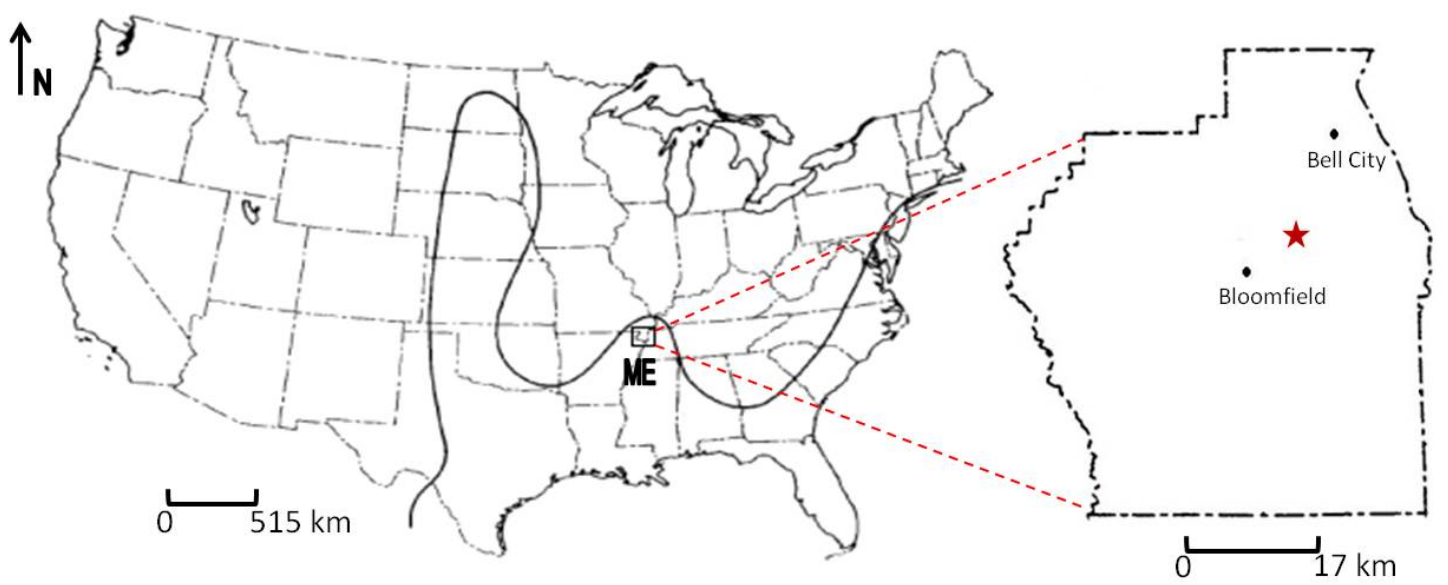

Paleontological and palynological studies done in Missouri and within the upper Mississippi Embayment province [5,7,9-17] have proven valuable in documenting the geological history of this region and also in resolving issues relating to the K-Pg boundary sequence in this area. Palynological work to date has focused largely on pollen and spores [7,17]. Although dinoflagellate cysts (dinocysts) have also received some attention in these efforts, research centered on dinocyst occurrences in this region should prove highly informative, and considerably augment our understanding of the unique geologic and biotic events characterizing the Cretaceous-Paleogene transition interval in this area.

Here, we examine the palynology of the K-Pg sequence in southeastern Missouri, particularly the Clayton Formation, using dinoflagellates as our primary focus. We use dinocyst occurrences recovered from the Clayton Formation and other K-Pg transition units to determine the timing of deposition of these units. We are particularly interested in whether a coquinite forming the basal part of the Clayton Formation is an end-K tsunamite deposit resulting from the Chicxulub impact event as proposed by previous workers [7,17]. By doing this, we hope to complement these previous efforts and to provide additional insight on the deposition of the Clayton Formation and its significance with respect to the K-Pg impact event. 


\section{Geologic Setting}

The K-Pg sequence near the head of the Embayment in Missouri, Tennessee, Illinois and in parts of northern Mississippi is represented by the Upper Cretaceous Owl Creek Formation, the uppermost member of the Ripley Group, and by the Paleocene Clayton and Porters Creek Formations, both members of the Midway Group [1,2,5,10-12,18-23]. In most sections, the Owl Creek Formation is unconformably overlain by the Clayton and Porters Creek Formations. In Arkansas, the uppermost Maastrichtian deposits are represented by the Arkadelphia Formation; in Alabama and in parts of northern Mississippi, by the Prairie Bluff Chalk Formation [6,12,22,24]. In these areas, Paleocene deposits of the Clayton Formation overlie Late Cretaceous sediments.

In Missouri, exposures of the K-Pg transition interval are few. Those that occur are poorly exposed due to intense weathering [7], and also due to patchy occurrences of the Clayton Formation in the upper Mississippi Embayment region [14]. However, the K-Pg transition sequence has been studied at sites in New Madrid, Scott, and Stoddard Counties, Missouri [7,17].

At these sites, Campbell et al. [7] interpret the Clayton Formation as a possible tsunami-induced deposit generated by the end-Cretaceous Chicxulub bolide impact. The interpretation advanced [7] is that the entire Clayton Formation represents the product of a suspension cloud which settled as a $185 \mathrm{~cm}$ thick graded isochronous deposit. They identified the basal $30 \mathrm{~cm}$ of this unit as composed of an unsorted fossiliferous coquinite containing tektite-bearing rip-up clasts. Their arguments for supporting this interpretation involve two primary points: (1) the coquinite contains a dense assemblage of presumably reworked Cretaceous marine macrofossils and Late Cretaceous and Paleocene palynomorphs; and, (2) layers of impact microtektites occur within unfossiliferous rip-up clasts contained in the coquinite. Campbell et al. [7] interpret the microtektites as deriving from a cloud of hot Chicxulub impact ejecta deposited immediately following the impact. The layering derived from the fusion of hot microtektites with the sediment into which they fell. This was followed a short time later by the mobilization of the substrate by the arrival of an impact-generated tsunami. Rip-up clasts containing the now-solidified layers of microtektites were formed as the bottom sediment was broken up and re-suspended by tsunami turbulence with the consequent rip-ups then re-deposited as the tsunami waned.

More recently, these authors [17] restricted the tsunamite interpretation to the Clayton coquinite. They state that the coquinite formed as a post-Chicxulub impact-related Danian megatsunamite unconformably deposited over the Maastrichtian Owl Creek Formation. They propose that only the coquinite represents an end-Cretaceous tsunamite deposit. They suggest that the glauconitic and gray clays of the upper Clayton Formation above the coquinite were deposited as a transgressive systems tract in deeper water conditions as determined by ichnofossil, sedimentologic, invertebrate and palynofacies data.

K-Pg palynomorph taxa (pollen, spores, fungi, algae, dinoflagellates and acritarchs) have been recovered from the Clayton Formation by the above workers [7,16,17], who suggest that extensive sediment reworking has resulted in a mixed assemblage of late Cretaceous and Paleocene palynomorph taxa in the Clayton Formation, and particularly in the coquinite. Palynomorphs, including dinocysts, supported a Late Maastrichtian age for the Owl Creek Formation based on the presence of Manumiella seelandica and Kenleyia? sp., which they say [17] had their first appearance datum (FADs) in 
the latest Maastrichtian. They state that reworked Cretaceous dinocysts found in the Clayton Formation consist of the species: Dinogymnium acuminatum, Dinogymnium sp., and Lejeunecysta izerzensis. The following species, which they have reported from the Clayton Formation, and which they inferred as Danian are: Achomosphaera alcicornu, Senoniasphaera inornata, Cerodinium striatum, C. diebelii, Hafniasphaera graciosa, H. septata, Palaeocystodinium golzowense, Palynodinium grallator, and Phelodinium magnificum. According to these authors [17], these dinocysts, as well as pollen analysis, suggest a Danian age for the Clayton Formation. They also proposed a middle-late Paleocene age for the Porters Creek Formation using pollen and spores, but noted the presence of several Cretaceous dinocyst taxa (Dinogymnium acuminatum and Odontochitina porifera) in the Porters Creek Formation which they considered to be reworked.

\section{K-Pg Boundary Sequence at Bloomfield, Missouri}

Recent mining activities have unearthed fresh and unweathered surface exposures of the K-Pg transition sequence near Bloomfield, Missouri (Figure 1). Our work is based on a new exposure on Crowley's Ridge, located about $4 \mathrm{~km}$ south-south-west of the Stoddard County site studied previously [7,17]. Figure 2 shows the K-Pg units at our locality.

\subsection{Owl Creek Formation}

At our locality, $1.3 \mathrm{~m}$ of the uppermost Owl Creek Formation is exposed above the base of a mining pit, and is composed of brown micaceous, quartz-rich, fossiliferous, silty, very fine sand (Figure 3A). Cretaceous marine macrofossils, such as cephalopods and bivalves, are commonly preserved in this formation at this site (Figure 3A).

\subsection{Clayton Formation}

At our site, the Clayton Formation lies unconformably above the Owl Creek Formation and has an overall measured thickness of $2.2 \mathrm{~m}$. Long, sinuous burrows 1-2 cm in diameter of the ichnofossil Thalassinoides (Figure 3C,D) progress downward from the Clayton Formation into the Owl Creek Formation. The Clayton Formation is a green, glauconitic, muddy sand with a fossiliferous lag concentrated within the basal $75-100 \mathrm{~cm}$. The lag is cemented with calcite, and in places the lag becomes a coquinite that is whitish in color (Figure 2). The coquinite at our site is discontinuous and broken into discrete pods separate from one another. A glauconitic clay matrix surrounds the whitish coquinite pods (Figure 3B). The coquinite pods enclose reworked Late Cretaceous macrofossils (Figure 3B). At the Missouri sites studied earlier [7], the basal Clayton coquinite is described as continuous but variable in thickness. The coquinite at these sites also contains rip-up clasts, $3-20 \mathrm{~cm}$ in length and enclose layers of microtektites, as well as ooids, and sub-rounded quartz grains [7]. We have not recovered any such rip-ups at our locality.

Glauconitic mud of the Clayton Formation at our site continues for $30 \mathrm{~cm}$ above the fossiliferous coquinite. Above the glauconite, macrofossils become sparse with only shell remains and occasional molds of small bivalves preserved. The glauconitic mud grades upward into a gray, fine sandy clay which represents the upper Clayton Formation. The gray clay is $1.1 \mathrm{~m}$ thick and contains sparse 
occurrences of glauconite at its base. The gray clay lacks macrofossils completely. The contact between the glauconitic mud and gray clay is moderately burrowed. The glauconitic mud at our site is relatively thin compared to the outcrop studied by the previous authors, where they report it is $70 \mathrm{~cm}$ thick [7]. They describe the overlying gray mud as having a thickness of $65 \mathrm{~cm}$, whereas at our site, it is $1.1 \mathrm{~m}$ thick. They also recovered numerous Upper Cretaceous macrofossil fragments and limonitic burrows in the glauconitic mud, as well as manganese oxide pebbles in the gray mud [7], but such materials are absent at our site.

Figure 2. Bloomfield Missouri collecting site. (a) Sampled outcrop located in a mining pit freshly excavated at the time of collection. Black arrows indicate the locations of coquinite pods. (b) Stratigraphic column of the sedimentary sequence. The boundary between the Owl Creek and Clayton Formations is marked by an unconformity. The position of all samples collected for dinocyst analysis shown at right. Sample 6a was collected from the glauconitic mud below the glauconite-gray mud contact, and Sample $6 \mathrm{~b}$ from a burrow in the overlying gray mud above the contact.

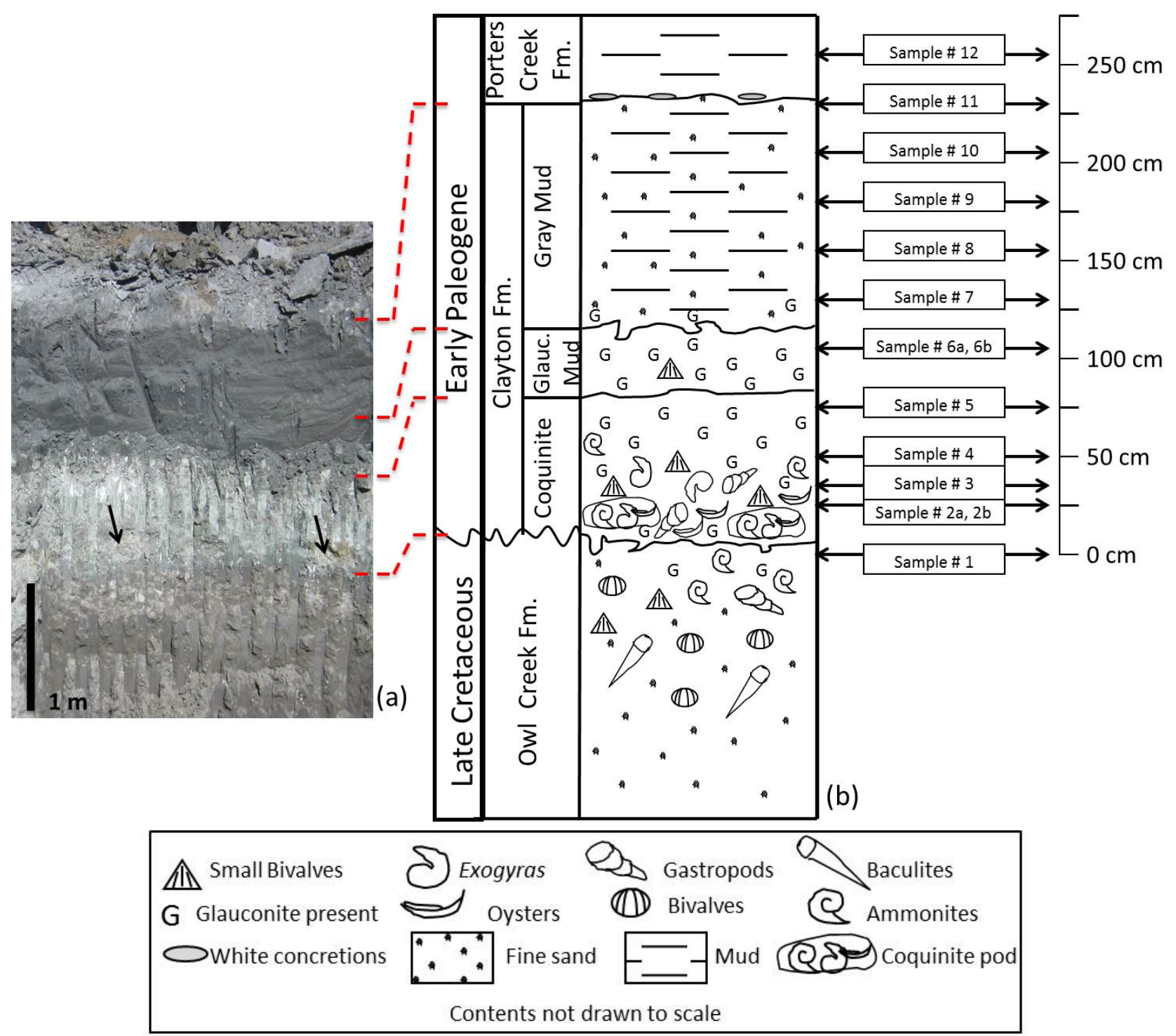


Figure 3. Sediment samples from our collecting site. (A) Fossiliferous Owl Creek fragment containing bivalves, gastropods and cephalopods within a muddy matrix. The fragment contains the index late Maastrichtian scaphite Discoscaphites iris (white arrow). (B) Coquinite forming the basal layer of the Clayton Formation showing the characteristic lithology and concentrated shell hash. (C) and (D) Fragments from the Owl Creek Formation contain burrows (outlined in white) of the ichnofossil Thalassinoides that progress downward from the Clayton Formation into the Owl Creek Formation. The burrows are filled with shell fragments and Clayton sediments.
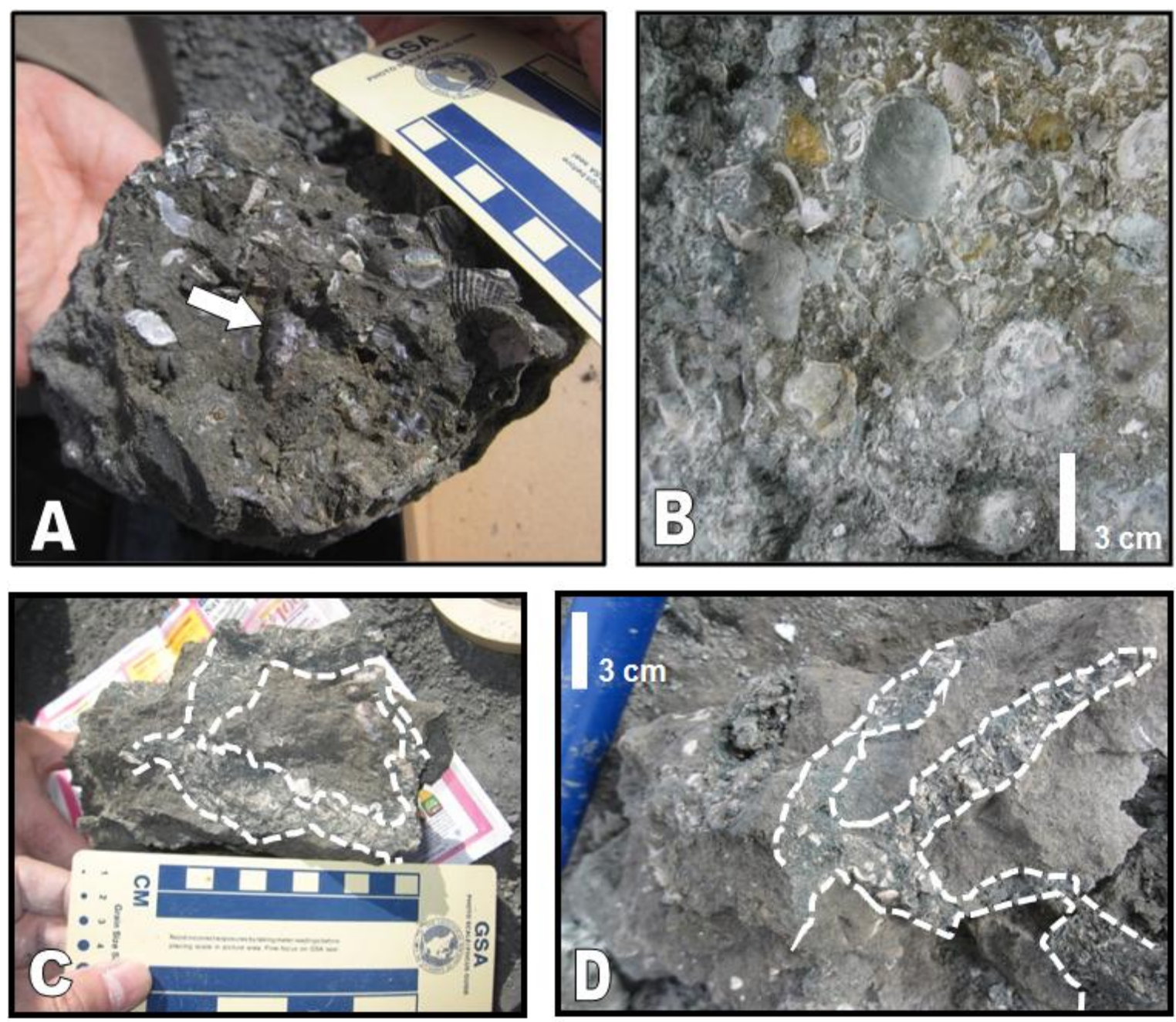

\subsection{Porters Creek Formation}

Overlying the Clayton Formation is the Porters Creek Formation, which, at its base, is an unfossiliferous, gray, silty claystone. The contact between the Clayton and the Porters Creek Formations appears gradational and contains whitish indurated concretions (Figure 2). The uppermost Clayton Formation is described as a hard claystone at the locality studied previously [7]. At our site there is no claystone, and the uppermost Clayton Formation terminates with gray mud. They state that the contact between the upper Clayton and Porters Creek Formations contained large $(>1 \mathrm{~m})$ torpedo-shaped, limonitic concretions at their site [7]. We find only small whitish non-limonitic concretions at the Clayton-Porters Creek contact noted above. 


\section{Methods}

\subsection{Collecting Procedures}

Fresh surfaces of the exposure studied here were provided by the excavation of the pit which occurred on the same day as sediment sample collection. A total of 14 sediment samples, each of approximately $500 \mathrm{~g}$, were collected using a paleo-pic and chiseled edges of rock hammers cleaned before and after every sample was taken. Samples were collected at approximately $25.5 \mathrm{~cm}$ intervals, except for Samples 3 and 4, which are more closely spaced (Figure 2 and Table 1). For each sample taken, sediment was collected over an interval approximately $5 \mathrm{~cm}$ above and below the horizons indicated in Figure 2.

Table 1. Samples Studied. List of sediment sample numbers, horizon in which samples were collected, number of slides analyzed for each sample and degree of microfossil recovery. High, more than 300 dinocysts per slide. Low, fewer than seven dinocysts per slide.

\begin{tabular}{|c|c|c|c|c|c|c|c|c|c|c|c|c|c|c|}
\hline Sample \# & 1 & $2 \mathbf{a}$ & $2 \mathbf{b}$ & 3 & 4 & 5 & $\mathbf{6 a}$ & $6 \mathbf{b}$ & 7 & 8 & 9 & 10 & 11 & 12 \\
\hline $\begin{array}{l}\text { Horizon sampled } \\
\text { above } 0 \mathrm{~cm} \text { datum }\end{array}$ & 0 & 25.5 & 25.5 & 38 & 50.5 & 76 & 101.5 & 101.5 & 127 & 152.5 & 178 & 203.5 & 229 & 254 \\
\hline \# Of slides analyzed & 2 & 3 & 2 & 1 & 1 & 1 & 1 & 1 & 1 & 1 & 1 & 1 & 1 & 1 \\
\hline Microfossil recovery & High & $\begin{array}{l}\text { Low } \\
\text { to High }\end{array}$ & $\begin{array}{l}\text { Low } \\
\text { to High }\end{array}$ & Low & Low & Low & High & High & High & High & High & High & High & High \\
\hline
\end{tabular}

We collected two samples at two horizons in the Clayton Formation, one just above the base of the coquinite (Samples 2a and 2b; Figure 2; and Table 1), and one at the glauconitic/gray mud contact (Samples 6a and 6b; Figure 2; and Table 1). Sample 2a was collected between coquinite pods in the lower Clayton Formation, while Sample $2 b$ was collected immediately below, but adjacent to, a coquinite pod. Sample 6a was collected in the glauconitic mud while Sample 6b was taken from a burrow filled with the overlying gray mud piped downward to the level of 6a.

\subsection{Palynological Preparation Procedures}

All of the sediment samples were processed using standard palynological preparation techniques [25]. Sediment samples were first treated with $10 \% \mathrm{HCl}$ to dissolve carbonates and secondly with $70 \% \mathrm{HF}$ solutions and centrifuged. Washing and centrifuging were then repeated several times to remove fine caustic material. Heavy liquid separation using $\mathrm{ZnBr}_{2}$ adjusted to a specific gravity of 2.0 was used to float palynomorphs. The residue was oxidized with $10 \%$ solution of $\mathrm{NH}_{4} \mathrm{OH}$. A $20-\mu \mathrm{m}$ sieve was used to concentrate dinoflagellates. The $20 \mu \mathrm{m}$ organic residues were stained using Safranin-red; and were then permanently mounted on slides for light microscopy analysis. Samples were prepared by Global Geolab Ltd., Medicine Hat, AB, Canada.

A total of 18 slides were produced from the 14 samples collected (Table 1). Most slides (13 out of the 18) yielded high microfossil recovery (Table 1) and exhibit abundant well-preserved cysts, with over 300 dinocysts mounted per slide. The coquinite showed variable preservation of taxa with most of the slides from the coquinite showing almost barren to low or poor recovery and contain 6-55 dinocysts mounted per slide. Consequently, multiple slides per sample were produced for the 
coquinite (Table 1). This variability may result from parts of the coquinite containing more limestone-rich material, which can affect preservation potential of palynomorphs [25]. Samples $2 a$ and $2 b$, which were retrieved from the lowermost coquinite, produced some slides that exhibited high recovery. Acritarchs were found in most samples.

\subsection{Microscope Procedures}

Transmitted light microscopy was used for identification of dinocysts and acritarchs. All slides were analyzed with a Nikon Eclipse E600 Polarizing Light Microscope (PLM) (Nikon Corporation, Tokyo, Japan) housed in the Micro-imaging lab at Brooklyn College. England Finder coordinates; size-measurements and descriptions of the dinoflagellates and acritarchs identified were recorded. Pictures and measurements were obtained using 2010 CellSens software on an Olympus light microscope (Olympus America, and Olympus Optical Co. Ltd., Tokyo, Japan) at the United States Geological Survey, Reston, VA, USA, or using an ocular micrometer on the Nikon Eclipse E600 PLM at Brooklyn College.

A total of 300 dinocysts and acritarchs were counted for each slide in productive samples. In unproductive samples, almost all taxa were counted and identified. Counts of unidentifiable taxa were the result of poor preservation and/or poor orientation. The number of unidentifiable specimens noted for each slide is also listed in the Supplementary. These data were then used to analyze the distribution of age-diagnostic important taxa within each sample and throughout the section. Species and genus names are based on the terminology of Fensome and Williams [26] as extended in Fensome, MacRae and Williams [27], with the exception of two newly assigned species [28] which follow principles used in Lentin and Williams [29] and Stover and Evitt [30]. Age ranges of taxa were determined using Palynodata [31], as well as existing available literature [5,6,13,14,25-74].

\section{Results: Marine Palynomorph Occurrences}

The Supplementary lists the 87 marine dinoflagellate and acritarch taxa that were identified, counted from our site. We extracted from this total data set 17 taxa based on the utility of their geologic ranges in timing events at the end of the Cretaceous, and arranged the selected taxa into three groups: Late Cretaceous taxa (4 species); Paleocene taxa (10 species); and short ranging K-Pg boundary-crossing taxa. Other taxa listed in the Supplementary we do not discuss further.

The absolute age of the K-Pg boundary that we use is $66.043 \pm 0.043 \mathrm{Ma}$ as determined by Renne et al. [75] who employed high-precision ${ }^{40} \mathrm{Ar} /{ }^{39} \mathrm{Ar}$ dating of $\mathrm{K} / \mathrm{Pg}$ boundary event tektites from Beloc, Haiti and bentonites from the Hell Creek region and Hauso Flats section in northeastern Montana. We realize that the age determined by these authors [75] readjusts the age of the $\mathrm{K} / \mathrm{Pg}$ boundary and will also alter the first occurrence (FO) absolute ages of the known earliest Danian index dinoflagellate species. In recent palynological work, Crouch et al. [74] takes the same approach in readjusting the boundary to $66 \mathrm{Ma}$. We believe that this adjustment of the age of the K-Pg boundary downward will adjust the absolute ages determined by Williams et al. [68] of Senoniasphaera inornata, Damassadinium californicum and Carpatella cornuta, but this does not alter the observations of these authors that the FO of $S$. inornata, and subsequent FOs of $D$. californicum and C. cornuta takes place

after the K-Pg boundary event. Our age designations for the species discussed below are taken from 
the geologic ranges given for them by the authorities identified in our descriptions of these species. The phenomenon of diachroneity is known to exist at the K-Pg boundary in which the FO or last occurrence (LO) of a species can vary by location. This phenomena has been discussed by Brinkhuis et al. [35] who analyzed the distribution patterns of some temperature-sensitive organic walled dinocysts (i.e., Palynodinium grallator) and concluded that such taxa experienced migration across the K-Pg boundary as a response to global cooling related to the K/Pg impact.

\subsection{Late Cretaceous Taxa}

Late Cretaceous taxa are those having stratigraphic ranges terminating at the top of the Maastrichtian. None of the taxa we treat in this section are known to be diachronous at the K-Pg boundary.

\subsubsection{Pierceites pentagonus, Figure 4a}

Pierceites pentagonus is distinguished by having a pentagonal outline, one apical and two antapical protrusions, and an archeopyle that involves three intercalary plates [45]. A late Maastrichtian age has been confirmed for P. pentagonus [41,71]. At our site, P. pentagonus occurs in the uppermost Owl Creek Formation (Sample 1) and in the basal coquinite (Samples 2a and 2b) of the Clayton Formation where it is last recorded.

Figure 4. Cretaceous Taxa. Scale bar applies to all images. (a) Pierceites pentagonus, Sample 2a, slide BC2-11a: N66/2. (b) Dinogymnium sp., Sample 2b, slide BC2-11b: H68/2. (c) Riculacysta amplexa, Sample 1, slide BC2-12: J38. (d) Phelodinium tricuspe, Sample 2a, slide BC2-11a: L35.

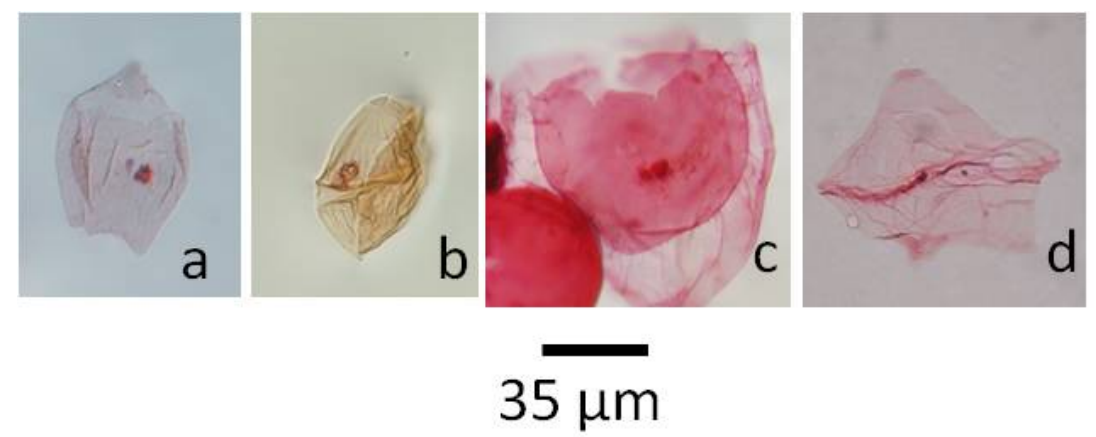

\subsubsection{Dinogymnium sp., Figure 4b}

This taxon is characterized by having a bi-conical outline, a well-developed cingulum and ridges that are present longitudinally on the epicyst and hypocyst; its archeopyle is small and located at the anterior apex of the dinocyst. Species of the genus Dinogymnium do not cross the K-Pg boundary and appearances of this genus in younger strata are considered reworked [44,67,68]. At our site, Dinogymnium sp. is recorded in the uppermost Owl Creek Formation (Sample 1) and in the basal coquinite (Samples 2a and 2b) of the Clayton Formation where it is last recorded. 


\subsubsection{Riculacysta amplexa, Figure 4c}

Riculacysta amplexa is circumcavate with slender process-like interconnections between the autophragm and ectophragm that are most prevalent near ventral margins. The ectophragm is thin, the endocyst is spherical to slightly lobate, and the archeopyle is apical. $R$. amplexa is known to stratigraphically occur in the late Maastrichtian [42,72]. R. amplexa occurs in the uppermost Owl Creek Formation (Sample 1) and is last recorded in the lowermost coquinite of the Clayton Formation (Sample 2b).

\subsubsection{Phelodinium tricuspe, Figure 4d}

The taxon Phelodinium tricuspe (= Phelodinium tricuspis) has a geologic range known to terminate at the end of the Cretaceous [62]. It has been noted that $P$. tricuspe has occasionally been recorded from Paleocene sediments and its occurrence may range across the K-Pg boundary, however the last reliable occurrence of typical specimens of this taxon has been documented from the upper Maastrichtian [62]. P. tricuspe is a cornocavate, peridinioid cyst composed of two wall layers. The endophragm and periphragm are closely appressed but can be seen to separate in the antapical and apical regions. P. tricuspe differs from $P$. magnificum which has a cyst that is wider than it is long, a different shaped archeopyle and antapical horns which are almost equal in length. At our site, P. tricuspe has been recorded in the uppermost Owl Creek Formation (Sample 1) and occurs last in the lowermost coquinite (Sample 2a).

\subsection{Paleocene Taxa}

Paleocene taxa originate in the early Paleocene. The K-Pg boundary is generally marked by the extinction of late Cretaceous taxa and the initial presence of distinctive Danian species.

\subsubsection{Carpatella cornuta, Figure 5a-c}

In our material, Carpatella cornuta can be characterized by its ellipsoidal cyst composed of two wall layers that are closely appressed, the cyst wall is thick and dark in color; it has one apical and antapical horn-like protrusions and contains a precingular archeopyle [37]. At our site, C. cornuta appears in three samples of the Clayton Formation: first is in the lowermost coquinite (Sample 2b), second in a burrow located in the glauconitic mud but filled with overlying gray mud (Sample 6b), and last in the lowermost Porters Creek Formation (Sample 12). C. cornuta has an early Danian to Selandian age assignment, and an absolute age of 64.75-59.95 Ma in northern mid-latitudes as discussed for this species by previous authors [68]. This absolute age has not been adjusted to consider the more recently determined age of the K-Pg boundary of $66.043 \pm 0.043 \mathrm{Ma}$ [75], nonetheless, the FO of this species is one that marks the early Danian $[6,45,51]$.

\subsubsection{Damassadinium californicum, Figure 5d,e,g,h}

Damassadinium californicum and associated D. californicum intergrades Figure 5i,j,m,n (intergrades between D. californicum and the genus Fibrocysta, or between the genus Cordosphaeridium)—which 
are clearly part of the D. californicum lineage [55]—were counted separately. In our samples, both Damassadinium californicum and $D$. californicum intergrades occur through most parts of the Clayton Formation. D. californicum is distinguished by having a spheroidal to ovoidal central body, a prominent apical protrusion and tabulation consisting of high penitabular septa that are broad and open. D. californicum has a Danian age assignment and an absolute age of 64.75-60.33 Ma in Northern Hemisphere mid-latitudes [68]. This absolute age has not been adjusted to consider the more recently determined age of the K-Pg boundary, but this species FO also marks the early Danian [47,51]. The FO of such forms at our site is in the basal coquinite (Sample 2b). D. californicum and D. californicum intergrades do not occur in the middle and upper coquinite (Samples 3-5) but reappear in the glauconitic mud (Sample 6a) of the Clayton Formation. Its presence is consistent from the glauconitic mud and upwards throughout the rest of the overlying sampled section (Sample 6a-12). D. californicum also increases in abundance with its highest quantity occurring in the Porters Creek Formation (Supplementary Information).

\subsubsection{Senoniasphaera inornata, Figure 5o-q}

Senoniasphaera inornata is a cavate cyst composed of an endophragm and periphragm that are generally smooth; however a faint cingulum and slight paratabulation may be present. According to Hultberg [51], S. inornata can have a spherical to slightly lobate endophragm, and the periphragm is described to mimic the shape of the endophragm. However, the holotype of this species contains a spherical endophragm and periphragm. S. inornata has a Danian age assignment and an absolute age of 64.95-62.6 Ma in Northern Hemisphere mid-latitudes [68]. Although this age has not been adjusted like the previous taxa discussed, its FO still marks the early Danian and it is commonly used as a K-Pg boundary marker [6,51,55]. Specimens that we counted and identified as S. inornata also have spherical wall layers, and only resemble the holotype. $S$. inornata only occurs in the basal coquinite of the Clayton Formation in our section (Samples $2 \mathrm{a}$ and $2 \mathrm{~b}$ ) where it is last recorded in Sample $2 \mathrm{~b}$.

\subsubsection{Xenocodinium lubricum, Figure $5 \mathrm{~s}-\mathrm{v}$}

The first occurrence of Xenicodinium lubricum can be used as a marker species to identify the basal Paleogene [65], and indicates the last and most upper zonule of the S. inornata Subzone established by Hansen [47]. X. lubricum is characterized by an ellipsoidal cyst with relatively thick walled theca that is granular on the outer surface. It also has a characteristic short membrane located on the margins of the cyst that truncate evenly, distally and makes the outer margins appear furry or hairy-like [57]. $X$. lubricum is extremely rare in our slides and is first recorded in the gray mud of the Clayton Formation at our site (Sample 7). It is also occurs in Samples 9-11 where it is last recorded.

\subsubsection{Lanternosphaeridium reinhardtii, Figure 5y,z,aa}

Lanternosphaeridium reinhardtii is a relatively new species and is potentially useful for distinguishing the basal Danian [6,73]. L. reinhardtii is characterized by an ovoid endocyst with prominent, long apical and shorter antapical spikes. If it is dorso-ventrally compressed, a bilateral, symmetrical wing or butterfly shape can be seen which is characteristic of the holotype [6]. L. reinhardtii appears three 
times in Sample $2 \mathrm{~b}$ of the basal coquinite. A poorly preserved specimen of the genus Lanternosphaeridium, possibly L. lanosum?, as determined by the possession of shorter endocystal spikes, Figure 5ab,ac, occurs in the Owl Creek Formation (Sample 1) as well as in the coquinite of the basal Clayton Formation at our site (Samples 2a and 2b).

Figure 5. Paleocene Taxa. Scale bar in (s) applies to all images except for $(\mathrm{t}, \mathrm{u}, \mathrm{v})$. (a-c) Carpatella cornuta (upper, mid and lower foci), Sample 6b, slide BC-7b: T34. (d) Damassadinium californicum, Sample 12, slide BC-1: D41. (e) D. californicum, Sample 7: slide BC-6: D62. (f) Senegalinium simplex, Sample 6b, slide BC-7b: C36. (g,h) D. californicum (upper and lower foci), Sample 2b, slide BC2-11b: H48. (i,j) D. californicum intergrades (upper and lower foci), Sample 9, slide: BC-4: M55/2. (k) Arvalidinium cristatum, Sample 6b, slide BC-7b: F64/4. (I) Senegalinium iterlaaense, Sample 12, slide BC-1: V48. (m,n) D. californicum intergrades (upper and mid foci), slide BC-8: L62/2. (o-q) Senoniasphaera inornata (upper, mid and lower foci), Sample 2b, slide BC2-11b: L33. (r) Deflandrea phosphoritica, Sample 12, slide BC-1: F42. (s) Xenicodinium lubricum, Sample 7, slide BC-6: G64/1. (t-v) X. lubricum (same specimen as (m) magnified 100×, (upper, mid and lower foci). (w,x) Hafniasphaera hyalospinosa (upper and mid foci), Sample 8, slide BC-5: O50. (y,z,aa) Lanternosphaeridium reinhardtii (upper, mid and lower foci), Sample 2b, slide BC2-11b: E54/3. (ab,ac) Lanternosphaeridium lanosum? (upper and lower foci), Sample 1, slide BC-12: H38/1.

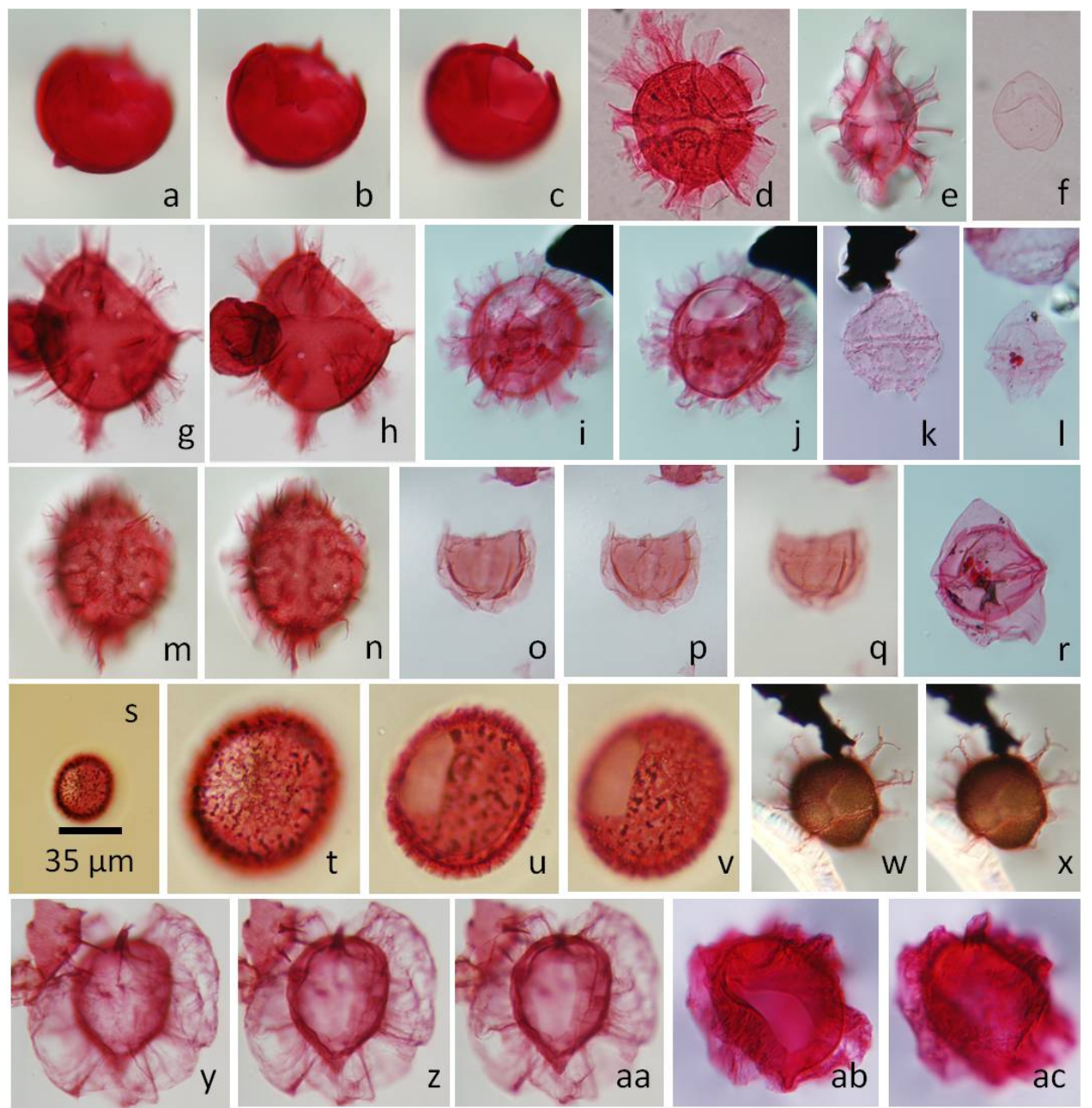




\subsubsection{Senegalinium simplex, Figure $5 \mathrm{f}$}

Senegalinium simplex is a small to medium sized, thin-walled, peridinioid dinoflagellate that has been described and recorded from the Upper Paleocene in the Aquia Formation in Virginia and from the Lower Paleocene Ellenton Formation in Georgia and South Carolina [28]. Senegalinium simplex is proximate and circumcavate, and is often found as an isolated endocyst. The endocyst can have an oval to peridinioid shape and is smooth. Senegalinium simplex is distinguished by its short apical horn, approximately equal, short antapical horns, and a hexagonal precingular archeopyle. Tabulation is only indicated by the archeopyle and less clearly by the cingulum. Senegalinium simplex clearly differs from ?Andalusiella rhombohedra, which has one prominent longer antapical horn and a significant apical horn in comparison. Senegalinium simplex consistently occurs throughout the section and within each formation at our site, with the exception of Samples 4, 5 and 11 where it is not recorded. As noted in the Supplementary, this species is a common constituent of Sample 1, which was taken from the top of the late Maastrichtian Owl Creek Formation. We thus suggest that in contrast to its occurrence in the Atlantic Coastal Plain, in Missouri this species ranges downward into the Late Maastrichtian, and thus is actually a K-Pg boundary crossing species.

\subsubsection{Hafniasphaera hyalospinosa, Figure $5 \mathrm{w}, \mathrm{x}$}

According to Hansen [47,48], species of Hafniasphaera first occur above the K-Pg boundary in the Danian with the exception of Hafniasphaera fluens, which ranges into the Late Cretaceous [47]. At our site, specimens of Hafniasphaera sp., occur in the Owl Creek Formation and throughout most of the studied section (Supplementary Information). Hafniasphaera hyalospinosa is larger in size compared to $H$. fluens (the diameter of the central body of H. fluens is 32-37 $\mu \mathrm{m}$ ), and the material that the processes are composed of are brighter and appear glassy [47]. Good specimens of the Danian species, H. hyalospinosa first occurs in Sample 6a, and again from Sample 7 through Sample 11 of the upper Clayton Formation and is last recorded in the Porters Creek Formation, Sample 12 (Supplementary Information).

\subsubsection{Arvalidinium cristatum, Figure 5k}

Arvalidinium cristatum is a peridinioid that has been described and recorded in the lower Paleocene of the Ellenton Formation in South Carolina [28]. This species is a round, thin-walled, pale, cyst with a short apical horn and two short, unequal antapical horns. A. cristatum is distinguished by its shoulders and ornamentation of spines and penitabular/intratabular sutural crests that cover the outer wall. A. cristatum is found sparsely throughout our section and have been recorded in Samples 2a, 6b, 8 and 9 (Supplementary Information).

\subsubsection{Senegalinium interlaaense, Figure 51}

Senegalainium iterlaaense is a relatively new species that has been studied from localities in West Greenland and Denmark, where it is first described, and recorded in the middle Danian [61]. These authors indicate that the range of this species is middle Danian to lower Selandian. Senegalinium iterlaaense is distinguished by its small size, and possession of an apical and two almost equal antapical horns that are short or strongly reduced. The cingulum is broad and deep, and $S$. iterlaaense is composed of two 
wall layers that are slightly striated, these features are most prominent around the cingulum. At our section, $S$. iterlaaense first occurs in Sample $6 \mathrm{~b}$ of the Clayton Formation. Senegalinium iterlaaense is recorded in the gray mud of the upper Clayton Formation (Samples 7 and 9-11), and is also recorded in the lowermost Porters Creek Formation (Sample 12).

\subsubsection{Deflandrea phosphoritica, Figure 5r}

Deflandrea phosphoritica can be characterized by its peridinioid shape, almost equal antapical horns, a hyaline periphragm and a large cavate cyst [25]. The stratigraphic range of $D$. phosphoritica is from the early Eocene-Oligocene [26,62], however, this species has been recorded from late Paleocene sediments [25]. We found one specimen of D. phosphoritica in the basal Porters Creek Formation (Sample 12).

\subsection{Index Species for the Early Danian and the K-Pg Boundary}

Danian species commonly used as global indicators to identify the early Danian or used to mark the K-Pg boundary are: Carpatella cornuta; Damassadinium californicum; Senoniasphaera inornata; Xenicodinium lubricum; Lanternosphaeridium reinhardtii and most species of Hafniasphaera (e.g., H. hyalospinosa) $[6,41,43,44,47,54,55,68,69]$. Firth [41] noted that the K-Pg boundary could be approximated by the highest occurrence of $P$. grallator. Or as suggested by others, the boundary can be located by the lowest occurrence of $C$. cornuta [6,45,47,50,52]. More recently, Gedl [44] stated that the boundary could be approximated by the last occurrence of the Maastrichtian dinoflagellate, Dinogymnium sp., and the first occurrence of C. cornuta. Commonly used as a boundary marker to identify the K-Pg boundary and the earliest Danian is S. inornata [6].

Hansen [47] established the Damassadinium californicum (= Danea mutabilis) Zone which he divided into two subzones: the lower S. inornata (= Chiropteridium inornatum) Subzone and the upper Hafniasphaera cryptovesiculata Subzone. He further divided the S. inornata Subzone into three different zonules in this order: the C. cornuta Zonule, Tectatodinium rugulatum (=Xenicodinium rugulatum) Zonule and the Xenicodinium lubricum Zonule. According to Hansen [47,48], the lower boundary of the $S$. inornata Subzone ranges before the Danian, and into the uppermost Maastrichtian P. grallator Zone, a conclusion that probably resulted from an identification error [50,55]. The first occurrence of $P$. grallator identifies the $P$. grallator Zone, which has been established from studies done in the North Sea [65].

\subsection{K-Pg Boundary-Crossing Taxa}

We consider dinoflagellates whose ranges extend from the late Cretaceous upward to at least the early Paleocene to be K-Pg boundary-crossing taxa. K-Pg boundary-crossing taxa include the following: Palynodinium grallator, Hafniasphaera fluens, Disphaerogena carposphaeropsis; Fibrocysta axialis; Fibrocysta ovalis; Isabelidinium? sp.; Tanyosphaeridium xanthiopyxides; Phelodinium magnificum; Fibradinium annetorpense; Hystrichokolpoma bulbosum; Deflandrea galeata; Renidinium gracile; Magallanesium densispinatum; and Trithyrodinium evitii. Of these boundary crossing taxa, $P$. grallator and H. fluens are particularly interesting. The absolute age of $P$. grallator is 
recorded from 66.77 to $64.75 \mathrm{Ma}$ in Northern Hemisphere mid-latitudes as discussed by previous authors (this age assignment has not been adjusted to accommodate the new age of the K-Pg boundary) [68]. $H$. fluens is the only species of its genus which crosses the K-Pg boundary [47]. These two species are described below.

\subsubsection{Palynodinium grallator, Figure 6a-c}

Palynodinium grallator is distinguished by having two wall layers, an apical archeopyle and two distinctive latero ventral pericoels that extend from epicyst to hypocyst, processes along the cingulum indicate paratabulation on the dorsal surface [69]. Firth [41] showed that in Georgia, the first occurrence of $P$. grallator occurred in the uppermost Maastrichtian. Additionally, he correlated organic walled phytoplankton assemblages from Maastrichtian and Danian strata in Georgia with dinoflagellate zonations of Wilson [70], Benson [32], and Hansen [47] and concluded that P. grallator does not occur above the K-Pg boundary. The P. grallator Zone, which is defined by the lowest occurrence of $P$. grallator, also identifies the uppermost Maastrichtian according to its incidence in regions of the North Sea [65].

Conversely, more recent palynological studies in El Kef, Tunisia record the FO of P. grallator at the K-Pg boundary and the last occurrence of this species within the lowermost Danian [35,46,59]. Brinkhuis et al. [35] recognized $P$. grallator as a temperature sensitive species whose occurrence varied latitudinally, thus exemplifying the phenomenon of diachroneity. In North America, accounts of $P$. grallator have not been found above the K-Pg boundary with the exceptions of two studies done on the K-Pg boundary in Georgia and Alabama $[6,46]$. The occurrence of $P$. grallator in Danian sediments is recorded as reworked in the Atlantic Coastal Plain [55]. Even if the last occurrence of P. grallator has been shown to extend into the Danian, its uppermost or last occurrence is still useful in helping to locate early Danian sediments. $P$. grallator has its highest abundance in our stratigraphically lowest sample of the uppermost Owl Creek Formation (Sample 1). The data provided in Table 2 shows that $P$. grallator is also present in the basal coquinite of the Clayton Formation (Samples 2a and 2b), but is less abundant when compared to its occurrence in the underlying Owl Creek Formation. P. grallator is not recorded above the lowermost coquinite (Samples $2 \mathrm{a}$ and $2 \mathrm{~b}$ ) at our site.

\subsubsection{Hafniasphaera fluens, Figure $6 \mathrm{v}, \mathrm{w}$}

Hafniasphaera fluens is the only species of Hafniasphaera that is found in the Maastrichtian, and crosses the K-Pg boundary [47] into the Paleocene. All other species of this genus occur above the K-Pg boundary [47]. The genus Hafniasphaera is distinguished by an ovoid cyst composed of two wall layers that contain numerous vesicles with variable distribution. Vesicles can also be seen within intratabular and distal processes. H. fluens is distinguished by its small-sized central body (32-37 $\mu \mathrm{m}$ in diameter) [47]. The processes of $H$. fluens bifurcate and trifurcate and to some extent resemble Spiniferites ramosus. H. fluens consistently occurs throughout the studied section in all formations with the exception of Samples 3-5. 
Figure 6. K-Pg boundary crossing taxa. Scale bar applies to all images. (a-c) Palynodinium grallator (upper, mid and lower foci), Sample 1, slide BC-12: R63/3. (d-f) Disphaerogena carposphaeropsis (upper, mid and lower foci), Sample 1, slide BC2-12: F33/1. (g) Fibrocysta axialis, Sample 2b, slide BC2-11b: F61/1. (h,i) Fibrocysta ovalis (upper and mid foci), Sample 2b, slide BC2-11b: T56. (j-l) Isabelidinium? sp. (upper, mid and lower foci), Sample 10, slide BC-3: B32/4. (m) Tanyosphaeridium xanthiopyxides, Sample 8, BC-5: O64/3. (n) Phelodinium magnificum, Sample 11, slide BC-2: G62/3. (o) Fibradinium annetorpense, Sample 6a, slide BC-7a: L59/3. (p-r) Hystrichokolpoma bulbosum (upper, mid and lower foci), Sample 9, slide BC-4: B48. (s) Deflandrea galeata, Sample 2a, slide BC2-11a: S61. (t) D. galeata, Sample 6b, slide BC-7b: H40/4. (u) Renidinium gracile, Sample 2b, slide BC2-11b, England Finder coordinate is unavailable and microscope coordinates (Nikon Eclipse E600 PLM) are provided: 23.5 and 99.9. (v,w) Hafniasphaera fluens (upper and lower foci), Sample 9, slide BC-4: P47/2-O47/4. (x) Magallanesium densispinatum, Sample 6b, slide BC-7b: K61. (y) Trithyrodinium evittii (upper and lower foci), Sample 1, slide BC2-12: N40. (z) T. evittii, Sample 10, slide BC-3: K49/4.
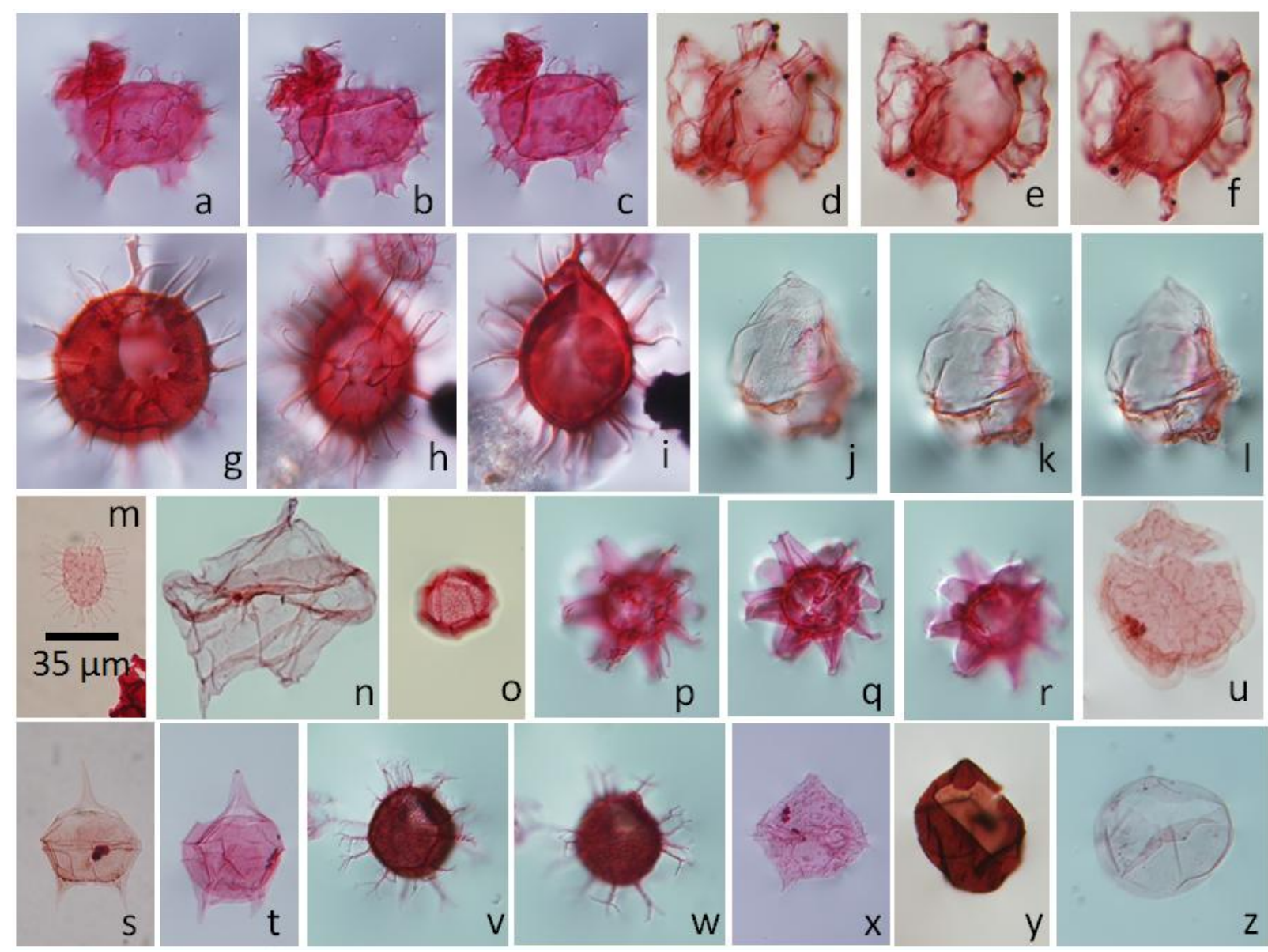

\section{Discussion}

\subsection{Age of the Cretaceous-Paleogene Sequence at Bloomfield, Missouri}

Figure 7 shows the geologic ranges of the geochronologically significant (GS) dinocysts discussed in Section 5 above as they are preserved in the sediments at our Bloomfield locality. We use this 
information, together with the known times of origination and extinction of these taxa, to infer the geologic ages of the Cretaceous-Paleogene transition units exposed in our Bloomfield section.

Figure 7. Stratigraphic ranges of 17 geochronologically significant (GS) dinoflagellate species in the Cretaceous-Paleogene sequence at Bloomfield, Missouri. Solid lines, species present in samples from the interval indicated at left. Dotted lines, species not present in samples from the interval indicated at left.

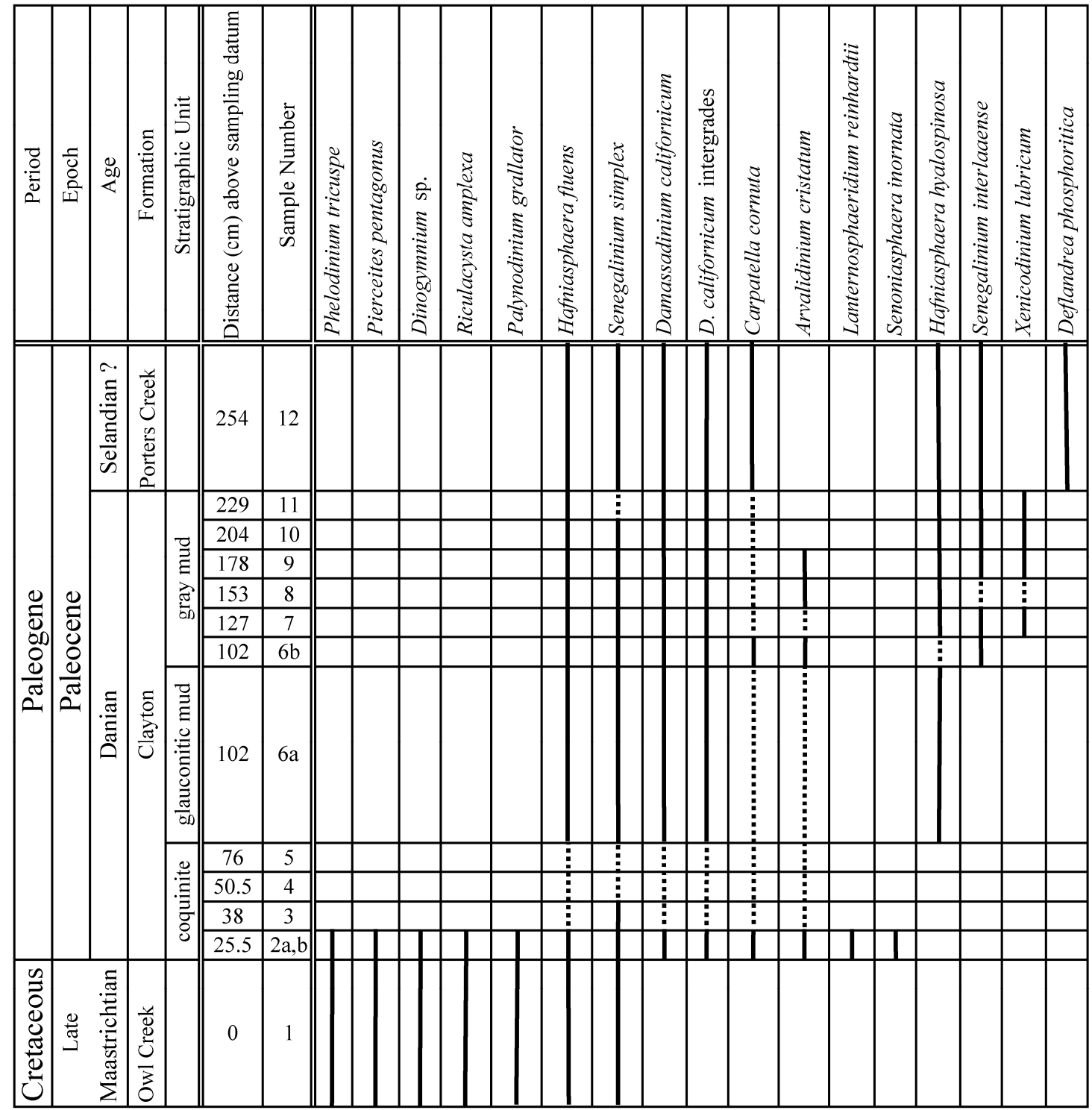

\subsubsection{Age of the Owl Creek Formation}

At our site, the uppermost Owl Creek Formation preserves Late Cretaceous index dinocysts: Pierceites pentagonus; Dinogymnium sp.; Riculacysta amplexa; and Phelodinium tricuspe. This supports the Late Cretaceous age already established for this unit [11,12,14,19]. In addition, we found two other GS species present in the Bloomfield Owl Creek Formation: Hafniasphaera fluens and Senegalinium simplex (Figure 7). H. fluens is the only species of this otherwise Paleocene genus known to extend downward into the Maastrichtian [47]. Based on its presence in the Owl Creek sample reported here, the same is true of $S$. simplex. Taken together these observations indicate that the 
distribution of dinocysts at the Bloomfield site is consistent with the interpretation of the uppermost Owl Creek formation as latest Maastrichtian.

\subsubsection{Age of the Clayton Coquinite}

The coquinite at our site is represented by Samples $2 a, 2 b$ and 3-5. Late Cretaceous dinocysts preserved in the basal coquinite (Samples $2 \mathrm{a}$ and $2 \mathrm{~b}$ ) are: P. tricuspe, P. pentagonus, Dinogymnium sp., and $R$. amplexa. All of these Late Cretaceous taxa have their last occurrences in the basal coquinite (Samples $2 \mathrm{a}$ and $2 \mathrm{~b}$ ) of our section recovered at and below $25.5 \mathrm{~cm}$ (Table 1, Figure 7, Supplementary Information). The following Paleocene dinoflagellates are also found in the coquinite: Carpatella cornuta, Senoniasphaera inornatum, Damassadinium californicum, D. californicum intergrades, and Lanternosphaeridium reinhardtii. These taxa are commonly used as global basal Danian indicators.

Other Paleocene taxa that occur in this part of the section are smaller pale peridinioids such as Arvalidinium cristatum, and the boundary crossing forms Senegalinium simplex and Hafniasphaera fluens. These occurrences indicate that the Clayton coquinite contains a mixed assemblage of Late Cretaceous and early Paleocene taxa.

The co-occurrence of all three early Danian index taxa (D. californicum, $S$. inornata and C. cornuta) in the coquinite are particularly interesting because according to Williams et al. [68] these three species make their first appearance in northern mid-latitudes about 500,000-700,000 years after the end of the Cretaceous. These observations indicate very strongly that the coquinite is Danian in age, and is separated in time from events marking the end of the Cretaceous. Its deposition would thus result from a sedimentary event occurring long after the Chicxulub impact and the K-Pg mass extinction, and would not be intimately associated with either one.

\subsubsection{Age of the Glauconitic and Gray Muds of the Clayton Formation}

Samples $6 \mathrm{a}$ and $6 \mathrm{~b}$ were taken from a thin horizon of glauconitic mud occurring above the coquinite: $6 \mathrm{a}$ from the glauconitic mud and $6 \mathrm{~b}$ from a burrow in the glauconitic mud filled with sediment of the overlying gray mud unit (Figure 7). Sample 6a is thus representative of the glauconitic mud while $6 \mathrm{~b}$ is representative of the gray mud. The Paleocene species Hafniasphaera hyalospinosa is first recorded in the glauconitic mud at our section, and is also present in the overlying gray mud. Damassadinium californicum, D. californicum intergrades, H. fluens, and Senegalinium simplex, which occur in the basal coquinite but not higher in the coquinite, re-appear in the glauconitic mud. C. cornuta and Arvalidinium cristatum, which also occur in the coquinite, re-appear in the gray mud. Xenicodinium lubricum is first recorded in Sample 7 at the base of the gray mud and is last recorded in Sample 11 from the uppermost gray mud. The first occurrence of Senegalinium iterlaaense is in the gray mud of Sample $6 \mathrm{~b}$. This species is continuously recorded to the top of the section.

These occurrences indicate that the gray mud and glauconitic mud of the Clayton Formation contain an assortment of Paleocene dinoflagellates and no taxa restricted to the Late Cretaceous. The recorded presence of $S$. iterlaaense in the gray mud is significant because the known stratigraphic range of $S$. iterlaaense begins in the middle Danian and ends in the lower Selandian. Since it is not present in underlying strata, it is presumably not reworked. Thus, its first occurrence in the gray mud should indicate a middle Danian age for this sediment. This is consistent with the early Danian age for the coquinite. 


\subsubsection{Age of Basal Porters Creek Formation}

The dinocyst Carpatella cornuta reappears in Sample 12 since last recorded in Sample 6a. Damassadinium californicum, and D. californicum intergrades are consistently recorded from the coquinite up to the Porters Creek Formation (Sample 12) where they occur more frequently in comparison to their occurrence in any other sample. S. iterlaaense is also found in the Porters Creek beds, as is Deflandrea phosphoritica, which is recorded for the first time in the lowermost Porters Creek Formation (Sample 12). This species is more commonly found in the basal Eocene [26,62], but has been found in late Paleocene sediments [25]. These occurrences, especially of S. iterlaaense and D. phosphoritica, suggest a possible middle to late Paleocene age for the Porters Creek Formation beds exposed at our site.

\subsection{Shell Concentrations and the Clayton Coquinite}

A variety of processes can produce shell-rich concentrations such as the Clayton coquinite. Some examples include storm-induced events, turbidity currents, regressive and transgression cycles, facies changes and mass-mortality events [76,77]. In our section, the contact between the uppermost Cretaceous Owl Creek Formation and the base of the coquinite in the lowermost Paleocene Clayton Formation is sharp and distinct. Following Kidwell [78,79], we interpret this contact to be the result of an erosive interval occurring prior to the deposition of the coquinite. We recognize that this erosive interval may in fact be an early phase of the depositional process that produced the coquinite, as for example, in the case of a storm driven event where erosion of the existing surface sediment precedes the mixing and re-deposition of this material. Following Kidwell [76-81], we suggest alternative hypotheses for the formation of the Clayton coquinite:

First, the Clayton coquinite may have resulted from a single fossil concentration event produced by a short-term process acting over a geologically brief period of time [77,79], e.g., tsunamis, turbidity currents, earthquakes, and storms. We would expect a dinoflagellate assemblage preserved in a lag deposit deriving from such a single event to be composed only of dinocysts from the most recently deposited sediments prior to the onset of the event and mixed with dinocysts reworked from older, underlying beds. Dinoflagellates younger than the event would not be present in the event lag.

Alternatively, the Clayton coquinite may result from complex multiple events that form time-averaged lag deposits revealing complex sedimentologic and stratigraphic histories [77,79], or from time-averaged hiatal concentrations that form from missing intervals of time due to erosional reworking, from sediment bypassing, or during times of slow sedimentation rates [76,77,80,81]. We would expect dinocysts preserved in such stratigraphic settings to be comprised of a complex assemblage, possibly preserving dinocysts across different environments and from different time intervals mixed with taxa present at the time of deposition.

\subsection{The Chicxulub Impact and the Clayton Coquinite}

The Clayton coquinite is separated from the Owl Creek Formation immediately beneath it by a single erosional surface. There are no additional erosional surfaces of similar magnitude visible within the coquinite. In addition, as reported here and in [7,17], the coquinite contains a mixed Maastrichtian and 
Danian dinoflagellate assemblage. It also contains abundant Late Cretaceous macrofossils including Discoscaphites iris, an index ammonite for the latest Maastrichtian in the Gulf Coastal Plain [82]. Except for the event defined by the Owl Creek-Clayton contact, there is no record in either the lithology of the coquinite, or in its fossil content, of multiple depositional events separated by major hiatal gaps.

However, understanding the details of the process by which the coquinite was deposited has proven more difficult. Campbell et al. [7] originally interpreted the entire Clayton Formation as the product of a tsunamite created by the End-Cretaceous Chicxulub bolide impact in the Yucatan region of Mexico. In their view, an impact generated tsunami mobilized the uppermost Owl Creek sediment as it surged up the Mississippi Embayment in the hours following the impact and then deposited the three Clayton sedimentary units during its waning phase shortly after that. They interpreted the presence of rip-up clasts containing layered tektites within the coquinite as evidence for this scenario of deposition from an impact-derived tsunami. More recently, these authors [17] have restricted the tsunamite to the coquinite. The overlying glauconitic and gray muds they attribute to depositional events occurring later in the Paleocene not related to the end-Cretaceous catastrophe.

Our view of the Clayton coquinite differs from both of these interpretations. If the deposition of the Clayton Formation in southeast Missouri resulted from a tsunami generated by the Chicxulub impact, we would expect that the macrofauna and microbiota preserved in this formation, and especially in the lowermost basal coquinite to be restricted to a late Maastrichtian age. A Chicxulub impact generated tsunami would rip up sediment from the Cretaceous Owl Creek seafloor, causing dispersed Cretaceous macrofauna to settle out primarily as the heavy fossiliferous component and the microbiota, including dinocysts, to settle out in more quiet water conditions associated with the waning phases of the tsunami. Tsunamite deposition would end have ended quickly, within weeks to months of the impact - far too rapidly to allow Danian forms to come into existence and be preserved in the coquinite. We discovered a mixed dinocyst assemblage in the basal coquinite composed of extinct Late Cretaceous taxa that have their last occurrences at this horizon: Dinogymnium sp.; Pierceites pentagonus; Riculacysta amplexa; Phelodinium tricuspe, and early Danian taxa: Senoniasphaera inornata; Carpatella cornuta; Damassadinium californicum; Lanternosphaera reinhardtii; Arvalidinium cristatum, along with the last occurrence of the short-range boundary-crossing taxon Palynodinium grallator.

The preservation of a rich Danian dinocyst complement in the coquinite suggests to us that the coquinite was deposited during the Danian, not as a Chicxulub impact tsunamite at the Cretaceous-Paleogene boundary. This view is strengthened by the observation that the Owl Creek-coquinite contact is burrowed (Figures 2 and 3C,D). None of the other $\mathrm{K} / \mathrm{Pg}$ sites at which tsunamites have been recognized have a bioturbated base. This indicates the presence of a hiatus between the Owl Creek Formation and coquinite which is hard to reconcile with the highly compressed time frame an end-Cretaceous tsunami origin requires for the deposition of the coquinite. The tektite-containing rip-up clasts which occur within the coquinite at the sites studied by Campbell et al. [7] also suggest a lengthy interval between tektite deposition and the formation of the clasts enclosing them. Rip-up clasts are fragments of a consolidated or semi-consolidated substrate broken up and re-suspended by an energetic, erosive flow event. Sediment consolidation implies the passage of considerable time, orders of magnitude more than the hours separating the arrival in what is now southeastern Missouri of impact tektites and the slower moving impact tsunami. We do not see Campbell et al.'s [7] attempt to 
side-step this problem by arguing that the still hot tektites would quickly fuse the sediment at the substrate surface into a coherent, resistant layer as a convincing argument because it appears unlikely to us that tektites would retain any heat at all after settling through the approximately $60 \mathrm{~m}$ of water depth that the sedimentary features suggests is a reasonable estimate of water depth in this region at the time. The tektites are very likely the result of the Chicxulub impact, but the origin of the clasts containing them is not; the clasts are the result of an event occurring well into the Danian.

The presence of the Middle Danian Senegalinium iterlaaense in the overlying gray mud (Figure 7), and the origination times for the species $S$. inornata, C. cornuta, D. californicum of 500,000 years or more into the Danian [69] puts this hiatus into a reasonable secular perspective, provides time for the evolution of Danian species preserved in the coquinite, and for the consolidation of the substrate, and suggests that the coquinite depositional event, although early Danian in age, occurred well after events marking the end of the Cretaceous, and was therefore completely unrelated to them. To maintain an impact-related, End-Cretaceous age for the coquinite one would have to invoke massive re-working of the coquinite microbiota and significant error in establishing the times of origin of the species noted above. We think this is highly unlikely.

\subsection{The Origin of the Clayton Coquinite}

Although there are a number of possibilities, consistent with the dinocyst data we present here, that could account for an early Danian Clayton coquinite not related to the Chicxulub impact, e.g., turbidity flow, slumping, storm deposition, we suggest that the most likely cause is early Danian sea level fluctuation.

\section{Sea Level Change}

The dinocyst data and sedimentary features of the coquinite suggest that the Clayton coquinite is a hiatal lag deposit resulting from an erosive interval produced by sea level cycling in the Mississippi Embayment. We postulate that during an early Danian regressive-transgressive phase of sea level change, suspension, mixing, and re-deposition of Maastrichtian Owl Creek sediment, tektites and other sedimentary material deriving from the end-K Chicxulub impact, and early Danian strata resulted in a Danian age coquinite containing a mixed assemblage of Late Cretaceous and early Danian macro and microbiota. The glauconitic mud and gray mud overlying the coquinite were produced in the early phases of the transgressive part of the cycle.

A most interesting aspect of the Cretaceous-Paleocene sequence in southeastern Missouri is that it lacks a strong End-Cretaceous impact signature. This probably is not due to an original absence of such a signature, as the tektite rip-ups in the coquinite attest, but rather to the overprinting of this signature by the erosive early Danian sea level cycling event we describe here. Equally interesting is the fact that there are other locations around the periphery of the Mississippi Embayment, particularly on its eastern side, at which an End-Cretaceous impact signature is also missing and at which a Danian age erosional surface has been identified [83-86]. In addition, the Cretaceous-Paleogene sequence in New Jersey also contains evidence of hiatuses in the Danian [55,56,87]. We suggest that some Mississippi Embayment occurrences, and possibly one or more of those in New Jersey also, are linked in the sense that they were produced by the same sequence stratigraphic erosive event. The effects of 
this event appear to vary geographically. At Starkville, Mississippi, the End-Cretaceous part of the sequence is obliterated [85,86]; at our site near Bloomfield, Missouri, some End-Cretaceous sedimentary features remain (e.g., the layered tektites); at sites in Monmouth County, NJ, End-Cretaceous events appear to be largely preserved undisturbed [87]. Local depositional and paleoenvironmental conditions seem to have played a guiding role in producing the disparate character with which the Late Cretaceous-Early Paleogene record is expressed in the sediments of the Atlantic and Gulf Coastal Plains and of the Mississippi Embayment. Pursuing these complex associations will undoubtedly become a prime focus of future work on this subject.

\section{Conclusions}

The Clayton Formation is a prominent lithologic unit of the Cretaceous-Paleogene transition in the Mississippi Embayment of the United States. At Bloomfield, Missouri, the Clayton Formation contains a basal coquinite preserving a mixed dinocyst assemblage of Maastrichtian taxa (e.g., Phelodinium tricuspe, Pierceites pentagonus, Riculacysta amplexa, Dinogymnium sp.) and early Danian taxa (e.g., Carpatella cornuta, Damassadinium californicum, Senoniasphaera inornata), along with the last occurrence of the short-range K-Pg boundary crossing taxon, Palynodinium grallator. A gray mud occurring above the coquinite in the middle of the Clayton Formation contains the mid-Danian dinoflagellate Senegalinium iterlaaense. The mixed assemblage of late Cretaceous and early Danian dinocysts in the Clayton coquinite weakens the hypothesis that the Clayton coquinite resulted from a tsunami thrown off by the end-Cretaceous Chicxulub impact event, and suggests instead that the Clayton coquinite is early Danian in age. The known times of first occurrence of the three Danian dinocysts listed above suggest that the coquinite is about a half million years younger than the Cretaceous-Paleogene boundary. The dinocyst data support the interpretation of the coquinite, not as an End-Cretaceous tsunamite, but rather as a transgressive lag deposit that occurred well after events marking the end of the Cretaceous, but before the middle Danian. Danian erosive events with approximately similar stratigraphic position have been described in Cretaceous-Paleogene sequences in other parts of the Mississippi embayment. We suggest that at least some of these events are expressions of the same episode of early Danian sea level change as we identify in southeastern Missouri.

\section{Acknowledgments}

We thank L. Edwards, United States Geological Survey, for assistance with dinoflagellate identifications, access to essential literature, and use of her microscope and supplementary software. We thank N. H. Landman, American Museum of Natural History, and R. Rovelli, Brooklyn College, for help with sample collection and other assistance in the field. We appreciate the help of C. Campbell, St. Louis Community College-Meramec, and the Nestle-Purina Company, in gaining access to the collection site. We acknowledge J. A. John, Stony Brook University, and A. Huska, City University of New York Graduate Center, for their support and comments throughout the development of this manuscript. We thank A. Dastas, D. Dastas, and J. Dastas for their support and contributions during this process. We also thank two anonymous reviewers for this journal for comments which materially improved this paper. 
This project was funded by the National Science Foundation Louis Stokes Alliance for Minority Participation Bridge to the Doctorate program; the Kenneth E. and Annie Castor Paleontological Society Award; a Brooklyn College Graduate Investment Program Research Award; and support from the Professional Staff Congress-City University of New York Award Program and from the N.D. Newell Fund of the American Museum of Natural History.

\section{Conflicts of Interest}

The authors declare no conflict of interest.

\section{References}

1. Pryor, W.A. Mesozoic-Cenozoic History of the Mississippi Embayment. In Guidebook to the Geology in the Vicinity of Cape Girardeau, Missouri Including Crowleys Ridge; Johnson, C.H., Ed.; Association of Missouri Geologists: Cape Girardeau, MO, USA, 1962; pp. 42-48.

2. Pryor, W.A.; Glass, H.D. Cretaceous-Tertiary clay mineralogy of the upper Mississippi Embayment. J. Sediment. Petrol. 1961, 31, 38-51.

3. Harrison, R.W.; Litwin, R.J. Campanian coastal plain sediments in southeastern Missouri and southern Illinois-Significance to the early geologic history of the northern Mississippi Embayment. Cretac. Res. 1997, 18, 687-696.

4. Cushing, E.M.; Boswell, E.H.; Hosman, R.L. General Geology of the Mississippi Embayment; Geological Survey Professional Paper 448-B; United States Government Printing Office: Washington, DC, USA, 1964.

5. Tschudy, R.H. Palynology of the Cretaceous-Tertiary Boundary in the Northern Rocky Mountain and Mississippi Embayment Regions. In Symposium on Palynology of the Late Cretaceous and Early Tertiary; Kosanke, R.M., Cross, A.T., Eds.; Special Papers Volume 127; Geological Society of America: Boulder, CO, USA, 1971; pp. 65-111.

6. Moshkovitz, S.; Habib, D. Calcareous nannofossil and dinoflagellate stratigraphy of the Cretaceous-Tertiary boundary, Alabama and Georgia. Micropaleontology 1993, 39, 167-191.

7. Campbell, C.E.; Oboh-Ikuenobe, F.E.; Eifert, T.L. Megatsunami Deposit in Cretaceous-Paleogene Boundary Interval of Southeastern Missouri; Special Papers Volume 437; Geological Society of America: Boulder, CO, USA, 2008; pp. 189-198.

8. Kennedy, W.J.; Landman, N.H.; Christensen, W.K.; Cobban, W.A.; Hancock, J.M. Marine connections in North America during the late Maastrichtian: Palaeogeographic and palaeobiogeographic significance of Jeletzkytes nebrascense Zone cephalopod fauna from the Elk Butte Member of the Pierre Shale, SE South Dakota and NE Nebraska. Cretac. Res. 1998, 19, $745-775$.

9. Grohskopf, J.G. Subsurface Geology of Mississippi Embayment of Southeast Missouri; Reports 37; Missouri Geological Survey and Water Resources: Rolla, MO, USA, 1955.

10. Stephenson, L.W. Owl Creek (Upper Cretaceous) Fossils from Crowley's Ridge, Southeastern Missouri; Geological Survey Professional Paper 274-E; United States Government Printing Office: Washington, DC, USA, 1955; pp. 97-137. 
11. Matthes, F.E. Cretaceous sediments in Crowleys Ridge, southeastern Missouri. AAPG Bull. 1933, 17, 1003-1015.

12. Stephenson, L.W.; Monroe, W.H. Prairie Bluff chalk and Owl Creek formation of eastern Gulf region. AAPG Bull. 1937, 21, 806-809.

13. Jones, E.L. Palynology of the Midway-Wilcox boundary in south-central Arkansas. GCAGS Trans. 1962, 12, 285-294.

14. Frederiksen, N.O.; Bybell, L.M.; Christopher, R.A.; Crone, A.J.; Edwards, L.E.; Gibson, T.G.; Hazel, J.E.; Repetski, J.E.; Russ, D.P.; Smith, C.C.; et al. Biostratigraphy and paleoecology of lower Paleozoic, Upper Cretaceous, and lower Tertiary rocks in U.S. Geological Survey New Madrid test wells, southeastern Missouri. Tulane Stud. Geol. Paleontol. 1982, 17, 23-45.

15. Harrison, R.W.; Litwin, R.J.; Repetski, J.E.; Mason, D.; Schultz, A. Results of Drilling in the English Hill Area, Benton Hills, Scott County, Missouri; Open-File Report 96-44; U.S. Geological Survey: Reston, VA, USA, 1996.

16. Eifert, T.L. The Cretaceous-Paleogene Transition in the Northern Mississippi Embayment, S.E. Missouri: Palynology, Micropaleontology, and Evidence of a Mega-Tsunamite Deposit. Ph.D. Thesis, Missouri University of Science and Technology, Rolla, MO, USA, 2009.

17. Oboh-Ikuenobe, F.E.; Spencer, M.K.; Campbell, C.E.; Haselwander, R.D. A portrait of Late Maastrichtian and Paleocene palynoflora and paleoenvironment in the northern Mississippi Embayment, southeastern Missouri. Palynology 2012, 36, 63-79.

18. Wade, B. The Fauna of the Ripley Formation on Coon Creek, Tennessee; Geological Survey Professional Paper 137; United States Government Printing Office: Washington, DC, USA, 1926.

19. Farrar, W. The Cretaceous and Tertiary Geology (of Southeast Missouri); 58th General Assembly Biennial Report; Missouri Geological Survey and Water Resources: Rolla, MO, USA, 1935.

20. Farrar, W.; McManamy, L. The Geology of Stoddard County, Missouri; 59th General Assembly Biennial Report; Missouri Geological Survey and Water Resources: Rolla, MO, USA, 1937.

21. Cooper, C.L. Smaller Foraminifera from the Porters Creek formation (Paleocene) of Illinois. J. Paleontol. 1944, 18, 343-354.

22. Dockery, D.T., III. Punctuated succession of Paleogene mollusks in the northern Gulf Coastal Plain. Palaios 1986, 1, 582-589.

23. Cope, K.H.; Utgaard, J.E.; Masters, J.M.; Feldmann, R.M. The fauna of the Clayton Formation (Paleocene, Danian) of southern Illinois: A case of K/P survivorship and Danian recovery. Bull. Mizunami Foss. Mus. 2005, 32, 97-108.

24. Becker, M.; Chamberlain, J.A., Jr.; Wolf, G. Chondrichthyans from the Arkadelphia Formation (Upper Cretaceous: Upper Maastrichtian) of Hot Spring County, Arkansas. J. Paleontol. 2006, 80, 700-716.

25. Traverse, A. Paleopalynology, 2nd ed.; Topics in Geobiology Series Volume 28; Springer: Dordrecht, The Netherlands, 2007.

26. Fensome, R.A.; Williams, G.L. The Lentin and Williams Index of Fossil Dinoflagellates; AASP Contributions Series 42; American Association of Stratigraphic Palynologists Foundation: Salt Lake City, UT, USA, 2004.

27. Fensome, R.A.; MacRae, R.A.; Williams, G.L. DINOFLAJ2, Version 1; Data Series No. 1; American Association of Stratigraphic Palynologists: Reston, VA, USA, 2008. 
28. Lucas-Clark, J. Small peridinioid dinoflagellate cysts from the Paleocene of South Carolina, U.S.A. Palynology 2006, 30, 183-210.

29. Lentin, J.K.; Williams, G.L. A Monograph of Fossil Peridinioid Dinoflagellate Cysts; Bedford Institute of Oceanography Report Series B-R-75-16; Bedford Institute of Oceanography: Dartmouth, NS, Canada, 1976.

30. Stover, L.E.; Evitt, W.R. Analyses of Pre-Pleistocene Organic-Walled Dinoflagellates; Stanford University Publications, Geological Sciences; Stanford University: Stanford, CA, USA, 1978; Volume 15.

31. Palynodata Inc.; White, J.M. Palynodata Datafile, 2006 version [CD-ROM]; Open File 5793; Geological Survey of Canada: Ottawa, ON, Canada, 2008.

32. Benson, D.G. Dinoflagellate taxonomy and biostratigraphy at the Cretaceous-Tertiary boundary, Round Bay, Maryland. Tulane Stud. Geol. Paleontol. 1976, 12, 169-233.

33. Brinkhuis, H.; Leereveld, H. Dinoflagellate cysts from the Cretaceous/Tertiary boundary sequence of El Kef, northwest Tunisia. Rev. Palaeobot. Palynol. 1988, 56, 5-19.

34. Brinkhuis, H.; Zachariasse, W.J. Dinoflagellate cysts, sea level changes and planktonic foraminifers across the Cretaceous/Tertiary boundary at El Haria, northwest, Tunisia. Mar. Micropaleontol. 1988, 13, 153-191.

35. Brinkhuis, H.; Bujak, J.P.; Smit, J.; Versteegh, G.J.M.; Visscher, H. Dinoflagellate based sea surface temperature reconstructions across the Cretaceous-Tertiary boundary. Palaeogeogr. Palaeoclim. Palaeoecol. 1998, 141, 67-83.

36. Brinkhuis, H.; Sengers, S.; Sluijs, A.; Warnaar, J.; Williams, G.L. Latest Cretaceous earliest Oligocene and Quaternary dinoflagellate cysts from ODP Site 1172, East Tasman Plateau. Proc. Ocean Drill. Program Sci. Results 2003, 189, 1-36.

37. Damassa, S.P. Carpatella cornuta Grigorovich 1969 (Dinophyceae): A member of the Aptiana-Ventriosum complex. Palynology 1988, 12, 167-177.

38. Damassa, S.P.; Goodman, D.K.; Kidson, E.J.; Williams, G.L. Correlation of Paleogene dinoflagellate assemblages to standard nannofossil zonation in North Atlantic DSDP sites. Rev. Palaeobot. Palynol. 1990, 65, 331-339.

39. Edwards, L.E.; Frederiksen, N.O.; Bybell, L.M.; Gibson, T.G.; Gohn, G.S.; Bukry, D.; Self-Trail, J.M.; Litwin, R.J. Overview of the Biostratigraphy and Paleoecology of Sediments from Five Course from Screven and Burke Counties, Georgia. In Geology and Paleontology of Five Cores from Screven and Burke Counties, Eastern Georgia; Edwards, L.E., Ed.; U.S. Geological Survey: Reston, VA, USA, 2001; pp. 1-19.

40. Edwards, L.E.; Goodman, D.K.; Witmer, R.J. Lower Tertiary (Pamunkey Group) Dinoflagellate Biostratigraphy, Potomac River Area, Virginia and Maryland. In Cretaceous and Tertiary Stratigraphy, Paleontology, and Structure, Southwestern Maryland, and Northeastern Virginia: American Association of Stratigraphic Palynologists Field Trip Volume Guidebook; Frederiksen, N.O., Krafft, K., Eds.; American Association of Stratigraphic Palynologists: Reston, VA, USA, 1984; pp. 137-152.

41. Firth, J.V. Dinoflagellate biostratigraphy of the Maastrichtian to Danian interval in the U.S. Geological Survey Albany Core, Georgia, U.S.A. Palynology 1987, 11, 199-216. 
42. Firth, J.V. Dinoflagellate assemblages and sea-level fluctuations in the Maastrichtian of southwest Georgia. Rev. Palaeobot. Palynol. 1993, 79, 179-204.

43. Firth, J.V. Upper Middle Eocene to Oligocene dinoflagellate biostratigraphy and assemblage variations in Hole 913B, Greenland Sea. Proc. Ocean Drill. Program Sci. Results 1996, 151, 203-242.

44. Gedl, P. Dinoflagellate Cyst Record of the Deep-Sea Cretaceous-Tertiary Boundary at Uzgru, Carpathian Mountains, Czech Republic. In The Palynology and Micropalaeontology of Boundaries; Special Publications Volume 230; The Geological Society of London: London, UK, 2004; pp. 257-273.

45. Habib, D.; Drugg, W.S. Palynology of sites 603 and 605, Leg 93, Deep Sea Drilling Project. Initial Rep. Deep Sea Drill. Proj. 1987, 93, 751-775.

46. Habib, D.; Olsson, R.K.; Liu, C.; Moshkovitz, S. High-resolution biostratigraphy of sea-level low, biotic extinction, and chaotic sedimentation at the Cretaceous-Tertiary boundary in Alabama, north of the Chicxulub crater. GSA Spec. Pap. 1996, 307, 243-252.

47. Hansen, J.M. Dinoflagellate stratigraphy and echinoid distribution in Upper Maastrichtian and Danian deposits from Denmark. Bull. Geol. Soc. Den. 1977, 26, 1-26.

48. Hansen, J.M. A new dinoflagellate zone at the Maastrichtian/Danian boundary in Denmark. Dan. Geol. Unders. Arbog 1979, 1979, 131-140.

49. Heilmann-Clausen, C. Dinoflagellate Stratigraphy of the Uppermost Danian to Ypresian in the Viborg 1 Borehole, Central Jylland, Denmark; Series A Volume 7; Danmarks Geologiske Undersøgelse: Copenhagen, Danmark, 1985.

50. Hultberg, S.U.; Malmgren, B.A. Dinoflagellate and planktonic foraminiferal paleobathymetrical indices in the boreal uppermost Cretaceous. Micropaleontology 1985, 32, 316-323.

51. Hultberg, S.U. Danian dinoflagellate zonation, the C-T boundary and the stratigraphical position of the fish clay in southern Scandinavia. J. Micropalaeontol. 1986, 5, 37-47.

52. Koch, R.C.; Olsson, R.K. Dinoflagellate and planktonic foraminiferal biostratigraphy of the uppermost Cretaceous of New Jersey. J. Paleontol. 1977, 51, 480-491.

53. Kurita, H.; McIntyre, D.J. Paleocene dinoflagellates from the Turtle Mountain Formation, southwestern Manitoba, Canada. Palynology 1995, 19, 119-136.

54. Landman, N.H.; Johnson, R.O.; Edwards, L.E. Cephalopods from the Cretaceous/Tertiary Boundary Interval on the Atlantic Coastal Plain, with a Description of the Highest Ammonite Zones in North America. Part 1. Maryland and North Carolina; American Museum Novitates No. 3454; American Museum of Natural History: New York, NY, USA, 2004.

55. Landman, N.H.; Johnson, R.O.; Edwards, L.E. Cephalopods from the Cretaceous/Tertiary Boundary Interval on the Atlantic Coastal Plain, with a Description of the Highest Ammonite Zones in North America. Part 2. Northeastern Monmouth County, New Jersey; Bulletin of The American Museum of Natural History No. 287; American Museum of Natural History: New York, NY, USA, 2004. 
56. Landman, N.H.; Johnson, R.O.; Garb, M.; Edwards, L.E.; Kyte, F.T. Cephalopods from the Cretaceous/Tertiary Boundary Interval on the Atlantic Coastal Plain, with a Description of the Highest Ammonite Zones in North America. Part 3. Manasquan River Basin, Monmouth County, New Jersey; Bulletin of The American Museum of Natural History No. 303; American Museum of Natural History: New York, NY, USA, 2007.

57. Morgenroth, P. Zur Kenntnis der Dinoflagellaten und Hystrichosphaeridien des Danien. Geologisches Jarhbuch 1968, 86, 533-578. (In German)

58. Mudge, D.C.; Bujak, J.P. Palaeocene biostratigraphy and sequence stratigraphy of the UK central North Sea. Mar. Petrol. Geol. 1996, 13, 295-312.

59. Nøhr-Hansen, H.; Dam, G. Palynology and sedimentology across a new marine Cretaceous-Tertiary boundary section on Nuussuaq, West Greenland. Geology 1997, 25, 851-854.

60. Nøhr-Hansen, H.; Dam, G. Emendation of Trithyrodinium evittii Drug 1967 and Trithyrodinium fragile (Davey 1969) an artificial split of one dinoflagellate cyst species-Stratigraphic and paleaoenvironmental importance. Grana 1999, 138, 125-133.

61. Nøhr-Hansen, H.; Heilmann-Clausen, C. Cerodinium kangiliense n. sp. and Senegalinium iterlaaense n. sp.-Two new stratigraphically important Paleocene species from West Greenland and Denmark. Neues Jahrb. Geol. Paläontol. Abh. 2001, 219, 153-170.

62. Powell, A.J. A Stratigraphic Index of Dinoflagellate Cysts; British Micropaleontological Society Publication Series; Springer: Berlin, Germany, 1992.

63. Pross, J.; Schmiedl, G. Early Oligocene dinoflagellate cysts from the Upper Rhine Graben (SW Germany): Paleoenvironmental and paleoclimatic implications. Mar. Micropaleontol. 2002, $45,1-24$.

64. Prowell, D.C.; Edwards, L.E.; Frederiksen, N.O. The Ellenton Formation in South Carolina-A Revised Age Designation from Cretaceous to Paleocene; U.S. Geological Survey Bulletin 1605-A; U.S. Geological Survey: Reston, VA, USA, 1985; pp. A63-A69.

65. Schiøler, P.; Wilson, G.J. Maastrichtian dinoflagellate zonation in the Dan Field, Danish North Sea. Rev. Palaeobot. Palynol. 1993, 78, 321-351.

66. Stanley, E.A. Upper Cretaceous and Paleocene plant microfossils and Paleocene dinoflagellates and hystrichosphaerids from northwestern South Dakota. Bull. Am. Paleontol. 1965, 49, 179-384.

67. Stover, L.E.; Brinkhuis, H.; Damassa, S.P.; de Verteuil, L.; Helby, R.J.; Monteil, E.; Partridge, A.D.; Powell, A.J.; Riding, J.B.; Smelror, M.; Williams, G.L. Mesozoic-Tertiary Dinoflagellates, Acritarchs and Prasinophytes. In Palynology: Principles and Applications; Jansonius, J., McGregor, D.C., Eds.; American Association of Stratigraphic Palynologists Foundation: College Station, TX, USA, 1996; Volume 2, pp. 641-750.

68. Williams, G.L.; Brinkhuis, H.; Pearce, M.A.; Fensome, R.A.; Weegink, J.W. Southern ocean and global dinoflagellate cyst events compared: Index events for the Late Cretaceous-Neogene. Proc. Ocean Drill. Program Sci. Results 2004, 189, 1-98.

69. Willumsen, P.S. Palynodinium minus sp. nov., a new dinoflagellate cyst from the Cretaceous Paleogene transition in New Zealand; Its significance and palaeoecology. Cretac. Res. 2006, 27, 954-963.

70. Wilson, G.J. Upper Campanian and Maastrichtian Dinoflagellate Cysts from the Maastricht Region and Denmark. Ph.D. Thesis, University of Nottingham, Nottingham, UK, 1974. 
71. Habib, D.; Miller, J.A. Dinoflagellate species and organic facies evidence of marine transgression and regression in the Atlantic Coastal Plain. Palaeogeogr. Palaeoclim. Palaeoecol. 1989, 74, $23-47$.

72. Moullade, M.; Watkins, D.K.; Oboh-Ikuenobe, F.E.; Bellier, J.-P.; Masure, E.; Holbourn, A.E.L.; Erbacher, J.; Kuhnt, W.; Pletsch, T.; Kaminski, T.A.; et al. Mesozoic biostratigraphic, paleaoenvironmental, and paleobiogeographic synthesis, equatorial Atlantic. Proc. Ocean Drill. Program Sci. Results 1998, 159, 481-490.

73. Brinkhuis, H.; Klinkenberg, E.; Williams, G.L.; Fensome, R.A. Two unusual new dinoflagellate cyst genera from the Bunde Borehole, Maastrichtian type area, southern Netherlands. Rev. Palaeobot. Palynol. 2000, 93-110.

74. Crouch, E.M.; Willumsen, P.S.; Kulhanek, D.; Gibbs, S. A revised Paleocene (Tuerian) dinoflagellate cyst zonation from eastern New Zealand. Rev. Palaeobot. Palynol. 2014, in press.

75. Renne, P.R.; Deino, A.L.; Hilgen, F.J.; Kuiper, K.F.; Mark, D.F.; Mitchell, W.S., III; Morgan, L.E.; Mundil, R.; Smit, J. Time scales of critical events around the Cretaceous-Paleogene boundary. Science 2013, 339, 684-687.

76. Beckvar, N.; Kidwell, S.M. Hiatal shell concentrations, sequence analysis and sea level history of a Pleistocene coastal alluvial fan, Punta Chueca, Sonora. Lethaia 1988, 21, 257-270.

77. Banerjee, I.; Kidwell, S.M. Significance of molluscan shell beds in sequence stratigraphy: An example from the Lower Cretaceous Mannville Group of Canada. Sedimentology 1991, 38, 913-934.

78. Kidwell, S.M. Palaeobiological and sedimentological implications of fossil concentrations. Nature 1985, 318, 457-460.

79. Kidwell, S.M. Patterns of Time Averaging in the Shallow Marine Fossil Record. In Taphonomic Approaches to Time Resolution in Fossil Assemblages; Kidwell, S.M., Behrensmeyer, A.K., Eds.; The Paleontological Society: Knoxville, TN, USA, 1993; pp. 275-300.

80. Kidwell, S.M. Condensed Deposits in Siliciclastic Sequences: Expected and Observed Features, In Cycles and Events in Stratigraphy; Einsele, G., Ricken, W., Seilacher, A., Eds.; Springer-Verlag: Berlin, Germany, 1991; pp. 683-695.

81. Kidwell, S.M. The Stratigraphy of Shell Concentrations. In Taphonomy: Releasing the Data Locked in the Fossil Record; Allison, P.A., Briggs, E.G., Eds.; Plenum Press: New York, NY, USA, 1991; Volume 9, pp. 211-279.

82. Larina, E.; Landman, N.H.; Garb, M.P.; Meyers, C.E. Rovelli, R. Upper Maastrichtian Ammonite Biostratigraphy of the Northeastern Gulf Coastal Plain. In Proceedings of 125th Anniversary Annual Meeting and Exposition of Geological Society of America, Denver, CO, USA, 27-30 October 2013; Paper No. 380-8.

83. Smith, C.C. The Cretaceous-Tertiary boundary at Moscow Landing, west-central Alabama. GCAGS Trans. 1997, 47, 533-540.

84. Hart, M.B.; Harries, P.J.; Cárdenas, A.L. The Cretaceous/Paleogene boundary events in the Gulf Coast: Comparisons between Alabama and Texas. GCAGS Trans. 2013, 63, 235-255.

85. Boas, C.; Garb, M.P.; Landman, N.H.; Rovelli, R.; Larina, E. The Significance of a Fossiliferous Spherule Bed at the K/Pg Boundary in Northern Mississippi. In Proceedings of 62nd Annual Meeting of Geological Society of America Southeastern Section, San Juan, Puerto Rico, 20-21 March 2013. 
86. Boas, C.; Garb, M.P.; Rovelli, R.; Larina, E.; Myers, C.E.; Naujokaityte, J.; Landman, N.H.; Phillips, G.E. New K/Pg Localities along the Eastern Gulf Coastal Plain: More Evidence of Impact and Tsunamis. In Proceedings of 125th Anniversary Annual Meeting and Exposition of Geological Society of America, Denver, CO, USA, 27-30 October 2013.

87. Landman, N.H.; Garb, M.P.; Rovelli, R.; Ebel, D.S.; Edwards, L.E. Short-term survival of ammonites in New Jersey after the End-Cretaceous Bolide impact. Acta Palaeontol. Pol. 2012, $57,703-715$.

(C) 2014 by the authors; licensee MDPI, Basel, Switzerland. This article is an open access article distributed under the terms and conditions of the Creative Commons Attribution license (http://creativecommons.org/licenses/by/3.0/). 